\title{
1 Diachronous retreat of the Greenland ice sheet during the last deglaciation
}

$2{ }^{1 *}$ Sinclair, G., ${ }^{1}$ Carlson, A.E., ${ }^{1}$ Mix, A.C., ${ }^{2}$ Lecavalier, B.S., ${ }^{3}$ Milne, G., ${ }^{1}$ Mathias,

3 A., ${ }^{1}$ Buizert, C., ${ }^{4}$ DeConto, R.,

$4{ }^{1}$ College of Earth, Ocean, and Atmospheric Sciences, Oregon State University, 5 USA

$6 \quad{ }^{2}$ Department of Physics and Physical Oceanography, Memorial University, Canada

$7 \quad{ }^{3}$ Department of Earth and Environmental Sciences, University of Ottawa, Canada

$8{ }^{4}$ Department of Geosciences, University of Massachusetts, Amherst, USA

9 *gsinclair@coas.oregonstate.edu, 607-319-1945

10 Abstract

11 The last deglaciation is the most recent interval of large-scale climate change that drove the

12 Greenland ice sheet from continental shelf to within its present extent. Here, we use a database

13 of673 published ${ }^{10} \mathrm{Be}$ ages from Greenland to document the spatial and temporal patterns of

14 retreat of the Greenland ice sheet during the last deglaciation. Following initial retreat of its

15 marine margins, most land-based deglaciation occurred in Greenland following the end of the

16 Younger Dryas cold period (12.9-11.7 ka). However, deglaciation in east Greenland peaked

17 significantly earlier (13.0-11.5 ka) than that in south Greenland (11.0-10 ka) or west Greenland

$18(10.5-7.0 \mathrm{ka})$. The terrestrial deglaciation of east and south Greenland coincide with adjacent

19 ocean warming. ${ }^{14} \mathrm{C}$ ages and arecent ice-sheetmodel reconstruction do not capture this

20 progression of terrestrial deglacial ages from east to west Greenland,showing deglaciation

21 occuring later than observed in ${ }^{10} \mathrm{Be}$ ages. This model-data misfit likely reflects the absence of

22 realistic ice-ocean interactions. We suggest that oceanic changes may have played an important 
23 role in driving the spatial-temporal ice-retreat pattern evident in the ${ }^{10} \mathrm{Be}$ data.

24 Key words: Greenland ice sheet; deglaciation; Holocene; ice-sheet models; model-data

25 comparison; surface exposure dating; radiocarbon dating

\section{1. Introduction}

During the global Last Glacial Maximum (LGM, 19-26 ka; Clark et al., 2009), the

28 Greenland ice sheet (GrIS) covered $\sim 65 \%$ more area than its present extent and in many places

29 extended to the continental shelf-slope break (Funder et al., 2011). Over the next $\sim 15 \mathrm{ka}$ as

30 temperatures increased, the GrIS retreated, reaching a smaller-than-present extent in the early to

31 middle Holocene (e.g., Carlson et al., 2014; Larsen et al., 2015; Young and Briner, 2015).

32 Superimposed on the general warming trend from the LGM to the middle Holocene were several

33 rapid climate fluctuations in the North Atlantic region. Abrupt warming initiated the Bølling

34 Interstadial period at $\sim 14.6 \mathrm{ka}$. Regional cooling initiated the Younger Dryas Stadial at $\sim 12.9 \mathrm{ka}$,

35 and abrupt warming defines the onset of the Holocene at $\sim 11.7$ ka (Shakun and Carlson, 2010;

36 Clark et al., 2012; Buizert et al., 2014). While the GrIS retreated in response to this most recent

37 interval of large-scale climate change, questions remain as to potential differences in how

38 particular regions behaved and whether retreat was synchronous across the island.

39 Several studies have examined regional to continental-scale deglaciation of Greenland, 40 using both proxy data and model results (e.g., Bennike and Björck, 2002; Dyke, 2004; Simpson

41 et al., 2009; Funder et al., 2011; Lecavalier et al., 2014; Young and Briner, 2015), with the

42 emergence of ${ }^{10} \mathrm{Be}$ surface exposure dating enabling increasingly detailed and precise

43 geochronological studies, improving our understanding of the patterns of ice retreat. Thirty-

44 seven studies using ${ }^{10} \mathrm{Be}$ ages to dateice-marginal systems around Greenland have been

45 published since 2007, addressing land-based retreat from the outer coast to the present margin 
46 (Figure 1). This rapidly growing dataset documentsspatial and temporal information of GrIS

47 responses to deglacial climate change, and can be used to independently validate ice-sheet 48 models.

49 Here, we assemble a complete database of all published ${ }^{10} \mathrm{Be}$ ages from Greenland. All 50 ages are recalculated with the most up-to-date production rate (Young et al., 2013a) and scaling

51 schemes, and are therefore internally consistent. We use this compilation and factor analysis to 52 investigate the spatial-temporal patterns of GrIS margin retreat. We also compare our results 53 against an updated ${ }^{14} \mathrm{C}$ database and a recent ice-sheet model simulation of the last deglaciation 54 (Lecavalier et al., 2014) to test whether the simulated GrIS response to deglacial climate change 55 agrees with observations, building on recent model-data comparisons for the Holocene when the 56 GrIS was smaller than its present extent (Larsen et al., 2015; Young \& Briner, 2015).

\section{2. Methods}

$58 \quad 2.1$ The ${ }^{10}$ Be Database

An extensive literature review revealed 37publications (as of May 2016) that include ${ }^{10} \mathrm{Be}$

60 exposure ages in Greenland (Figure 1, Table 1). A total of 673 ages have been published, with

61 between two and 47 ages per publication. Most studies focused on constructing a local to

62 regional ice-retreat chronology, although some use ${ }^{10} \mathrm{Be}$ ages to evaluate response of parts of the

63 GrIS to climatic events like the Younger Dryas,9.3 ka and $8.2 \mathrm{ka}$ events (Young et al., 2013b;

64 Larsen et al., 2016) or to constrain the thickness and extent of the GrIS during the LGM (e.g.,

65 Håkansson et al., 2007a). Several papers also investigated the behavior of local ice caps and

66 mountain glaciers separate from the main ice sheet (e.g., Kelly et al., 2008; Möller et al., 2010;

67 Levy et al., 2014; Lowell et al., 2013; Young et al., 2015; Larsen et al., 2016). All ages are 68 included in our database. 
All the data necessary to calculate ${ }^{10} \mathrm{Be}$ ages using the CRONUS-Earth online calculator

70 (Balco et al. 2008; hereafter the CRONUS calculator) were extracted from the original

71 publications. In case of ambiguity or missing data, corresponding authors were contacted to

72 provide original data. If ${ }^{26} \mathrm{Al}$ measurements were performed in the original study, ${ }^{26} \mathrm{Al}$

73 concentrations, uncertainties, and standards were included in the database to facilitate calculation

74 of ${ }^{26} \mathrm{Al}$ exposure ages. However, ${ }^{26} \mathrm{Al}$ ages were excluded from the data-model comparison

75 presented below, because only 90 samples included ${ }^{26} \mathrm{Al}$ ages in addition to ${ }^{10} \mathrm{Be}$ ages, and ${ }^{26} \mathrm{Al}$

76 ages were used in the original studies primarily to supplement ${ }^{10} \mathrm{Be}$ ages and test for inheritance.

77 In the original publications, slightly different standards were used for several fields in the

78 CRONUS calculator. To account for this, the following minor modifications were performed

79 with the original data to ensure the dataset is internally consistent. All granitic and gneissic

80 samples were assigned a density of $2.65 \mathrm{~g} \mathrm{~cm}^{-3}$, and all sandstone samples were assigned a

81 density of $2.38 \mathrm{~g} \mathrm{~cm}^{-3}$. Densities of granite/gneissic samples, where reported, ranged between

822.56 and $2.81 \mathrm{~g} \mathrm{~cm}^{-3}$; however, these were generally inferred instead of directly measured, so a

83 constant density assigned here is equally plausible and is internally consistent. In addition, all

84 samples were assigned zero post-exposure erosion. Some evidence of erosion was observed in

85 original studies, particularly in east Greenland (Levy et al., 2014; Håkansson et al., 2007b).

86 However, in most regions little to no post-exposure erosion was observed, and small-scale

87 glacial erosional features, such as polish and striae, were often observed, indicating the surfaces

88 are well preserved since deglaciation. The database includes both the assigned densities and

89 erosion rates and the original reported values for reference, although they are not included in our

90 analyses. 
No correction for isostatic uplift was included in the re-calculated ages for two reasons.

92 First, only threeof the original studies included an isostatic uplift correction for ${ }^{10} \mathrm{Be}$ ages(Kelly et

93 al., 2008; Young et al., 2011a; Rinterknecht et al., 2014). Including isostatic uplift in these two

94 studies changed ages by 2 to $9 \%$. Second, estimating the precise amount of isostatic uplift is

95 difficult, because local relative sea-level change near ice sheets is influenced by isostatic

96 adjustment of the solid Earth as well as changes in ocean surface height due to global meltwater

97 influx and local gravity changes associated with surface (ice-ocean) and internal (Earth

98 deformation) mass redistribution (Farrell and Clark, 1976; Milne and Shennan, 2013).Therefore,

99 estimating the amount of atmospheric depth change requires the use of an isostatic sea-level

100 model, which in turn requires estimating the position of the glacier margin, leading to somewhat

101 circular reasoning and calculations.

102 Once the database of published information was compiled, all ${ }^{10} \mathrm{Be}$ ages were re-

103 calculated using the CRONUS calculator, version 2.2 (http://hess.ess.washington.edu/).

104 Calculations using both the Northeast North American (Balco et al., 2009) and Arctic (Young et

105 al., 2013a) production rates were performed. Results from all five scaling schemes calculated on

106 the CRONUS calculator are reported in the database, along with information from the

107 publications necessary to reproduce these calculations or re-calculate ages with any future

108 changes to regional production rates and/or scaling schemes. In our analysis, we use ${ }^{10} \mathrm{Be}$ ages

109 calculated using the Arctic production rate (Young et al., 2013a) and the Lal/Stone time-varying

110 scaling scheme, with internal uncertainties. Use of alternate scaling schemes does not

111 significantly impact results; the internal uncertainty calculated with CRONUS for a given sample

112 is on average 6.1 times greater than the difference between the oldest and youngest ages

113 calculated from the different scaling schemes. The difference between re-calculated ages and 
114 reported ages is negligible for most recent publications (from 2011-2015), but is significant for

115 the 148 ages published between 2007 and 2010, where the median difference between reported

116 and re-calculated ages is $1.7 \mathrm{ka}$. The database is available in .xls, .kmz, and .shp form from the

117 U.S. National Climate Data Center. No published samples are excluded from this database; even

118 where ${ }^{10} \mathrm{Be}$ ages were excluded from analysis in the original publications they have been

119 included here to ensure the dataset is complete for future investigations, which may have

120 different research goals from those of the original publications.

121 A subset of ${ }^{10} \mathrm{Be}$ ages ( $\mathrm{n}=453$ samples) was compiled to investigate the main phase of

122 GrIS retreat from the LGM to the middle Holocene. The deglacial interval is defined here as

123 occurring between $21 \mathrm{ka}$ and the onset ofNeoglacial cooling around 4 ka (Clark et al., 2009;

124 Lecavalier et al., 2014; Larsen et al., 2015).This data set contains the same information as the

125 main database, but all 159 samples older than $21 \mathrm{ka}$ and all 39 samples younger than 4 ka were

126 excluded from the comparison a priori. Seven further sampleswere excluded from the dataset

127 because while they are older than 4 ka, they are 'old' outliers from late-Holocene moraines

128 (Levy et al., 2014; Winsor et al., 2014), likely due to inheritance from earlier exposure histories.

129 All ${ }^{10} \mathrm{Be}$ ages from pebbles on moraines were excluded, to avoid anomalously young ages due to

130 exhumation of small clasts. The only ${ }^{10} \mathrm{Be}$ study in Greenland to rely heavily on amalgamated

131 pebble samples due to a lack of suitable bedrock or boulder samples had widely scattered ages

132 spanning $\sim 8 \mathrm{ka}$ (Alexanderson and Håkansson, 2014). This suggests that the oldest ages could be

133 minimum limiting (i.e., constraining the younger limit of the potential age range of the moraine),

134 because the pebbles have likely experienced significant exhumation since deglaciation

135 (Alexanderson and Håkansson, 2014). 
In addition to the ${ }^{10} \mathrm{Be}$ database, a deglacial database of ${ }^{14} \mathrm{C}$ ages was constructed that

139 builds on the existing database of Dyke (2004) (Figure 2, Table 2). The ${ }^{14} \mathrm{C}$ database was used to

140 check ${ }^{10} \mathrm{Be}$ ages, testing the hypothesis that ${ }^{10} \mathrm{Be}$ ages are on average older than ${ }^{14} \mathrm{C}$ ages $;{ }^{14} \mathrm{C}$ ages

141 are by definition minimum limiting because they date death of organic material which grows

142 sometime after retreat of the ice sheet. While this ${ }^{14} \mathrm{C}$ database can also be used to test ice-sheet

143 model simulations, the comparison was not done here. The ice-sheet model was tuned in part to

144 the ${ }^{14} \mathrm{C}$ records (Lecavalier et al., 2014), so validating it with the ${ }^{14} \mathrm{C}$ database would introduce

145 an element of circularity. Like the ${ }^{10} \mathrm{Be}$ database, the ${ }^{14} \mathrm{C}$ database was constructed through a

146 detailed literature review. $791{ }^{14} \mathrm{C}$ dates and metadata were pulled from the original publications,

147 and re-calibrated using the IntCal13 calibration dataset in Calib14 (Reimer et al., 2013;

148 http://calib.qub.ac.uk). To maintain consistency across calculations from different research

149 groups, all marine ages were corrected for a constant 400 -year ${ }^{14} \mathrm{C}$ reservoir age (i.e., $\Delta \mathrm{R}=0$ ),

150 which is commonly used around Greenland (Dyke, 2004; Carlson et al., 2008; Jennings et al.,

1512006 ; 2014). Radiocarbon ages were then calculated as the median between the upper and lower

152 limits of all age distributions for both 1- and 2-sigma uncertainties. The ${ }^{14} \mathrm{C}$ database is available

153 in .xls, .kmz, and .shp form from the U.S. National Climate Data Center.

\section{2.3Factor Analysis of Cosmogenic and Radiocarbon Data}

155 Q-mode factor analysis (e.g., Imbrie and Van Andel, 1964) and associated transfer

156 functions have traditionally been applied to ocean sediment data in paleoceanography and

157 paleoclimate. This method is most commonly used with marine biological assemblages to

158 determine past ocean temperatures (e.g., Imbrie and Kipp 1971; Mix et al. 1999). Imbrie and van

159 Andel (1964) established the method for applying Q-mode factor analysis to geochemical data. 
160 This method takes a set of samples characterized by multiple variables, and extracts a set of

161 factors representing theoretical end member assemblages that can be combined in different

162 proportions to recreate the sample set. Q-mode analysis should be used with most geochemical

163 data, as opposed to R-mode analysis, because itsfactors represent end-member samples instead of

164 variables (ibid, Pisias et al. 2013). Q-mode factor analysis weights the relationships between all

165 variables and all samples equally, and therefore does not rely on apriori assignment of groups

166 based on perceived similarities and/or geographic location. This analysis will therefore provide

167 objective estimates of (1) the number of end-member assemblages explaining the majority of

168 variance within the samples; (2) the composition of these assemblages; and (3) the contributions

169 of these end members to each individual sample (Imbrie and van Andel 1964). Here, ${ }^{10} \mathrm{Be}$ and

$170{ }^{14} \mathrm{C}$ ages are evaluated using factor analysis to determine if a spatial pattern can be objectively

171 identified, and if this pattern can be related to paleoclimate records.

172 We performed the Q-mode analysis on normalized grid cell probability density functions

173 (PDFs). Figure 3 shows a schematic illustration of the process for assigning samples to grid cells

174 and building PDFs for the ${ }^{10} \mathrm{Be}$ factor analysis. First, ${ }^{10} \mathrm{Be}$ samples are sorted into grid cells. For

175 simplicity and to facilitate later data-model comparison, we have used the Huy3 $20 \mathrm{~km}$ model

176 grid cell to sort the samples (Lecavalier et al., 2014). We assigned ${ }^{10} \mathrm{Be}$ samples to their grid cells

177 by calculating the distance from the sample to the midpoint of each grid cell. The sample was

178 then placed into the nearest grid cell (1). Between 1 and 27 samples were located in each grid

179 cell. Next, a Gaussian distribution was calculated at 10-year intervals from 0 ka to the maximum

180 possible age of the sample (4-sigma greater than the re-calculated age, using the internal

181 analytical uncertainty as the 1-sigma uncertainty) (2). The Gaussians for all samples in a grid cell

182 are then summed to create a grid cell PDF (3). To avoid weighting the analysis to those grid cells 
183 with many samples, each grid cell PDF is normalized to an areaunder the curve of 1 (4).

184 Thesenormalized grid cell PDFs are then used for Q-mode factor analysis following Pisias et al.

185 (2013). A final varimax factor matrix is achieved by rotating a preliminary matrix calculated

186 with the retained significant orthogonal factors to maximize positive loadings of all factors. This

187 results in the retained factors explaining approximately equal amounts of variance (Imbrie and

188 van Andel, 1964).

189 The process for calculating factors for the ${ }^{14} \mathrm{C}$ database is identical to that for the ${ }^{10} \mathrm{Be}$

190 database, with the exception that instead of using all data points in a given grid cell, we calculate

191 the normalized PDF for only the oldest ${ }^{14} \mathrm{C}$ age in a gridcell. This controls for the fact that many

192 of the ${ }^{14} \mathrm{C}$ ages come from lake or marine cores, where only the oldest age is relevant for

193 determining minimum ice-retreat ages, and is also a way to identify the oldest minimum-limiting

$194{ }^{14} \mathrm{C}$ age in a given $20 \mathrm{~km}$ area.

\section{2.4Data-Model Comparison}

196 Our ${ }^{10} \mathrm{Be}$ database represents the most complete record of terrestrial GrIS retreat currently

197 available and can therefore be used as an independent validation tool for ice-sheet models. This

198 data set provides a framework to test the Huy3reconstruction of GrIS retreat from $\sim 19$ ka to the

199 present (Lecavalier et al., 2014). The ice-sheet reconstruction is based on a thermodynamic ice-

200 sheet model used in series with a glacial isostatic adjustment model of sea-level change. The ice

201 model was run at $20 \mathrm{~km}$ gridresolution. For this analysis, we considered model output of ice

202 extent at $1 \mathrm{ka}$ intervals. The model was forced from $19 \mathrm{ka}$ to the late Holocene using atmospheric

203 temperatures extrapolated from the GRIP $\delta^{18} \mathrm{O}$ temperature reconstruction. Certain model aspects

204 and parameters were varied to seek an optimal fit to both ice-extent data from the LGM through

205 to the present as well as a regional relative sea-level database (see Lecavalier et al. (2014) for 
detailed descriptions of model forcing and physics).

To facilitate comparison with the ice-sheet model reconstruction, each ${ }^{10} \mathrm{Be}$ sample from

208 the deglacial dataset was associated with a model grid cell as described in Section 2.2. Where

209 more than three samples were present in an individual grid cell, Chauvenet's criterion was used

210 to test for outliers (Balco, 2011). This is a gentle test for anomalous data, which compares each

$211{ }^{10} \mathrm{Be}$ age to the mean and standard deviation of the samples in a grid cell. If the sample deviation

212 exceeds the maximum assigned for a given number of samples, the sample is excluded from the

213 analysis. This method led to the exclusion of ten ${ }^{10} \mathrm{Be}$ ages. In an effort to maintain objectivity in

214 the data-model comparison, no further ${ }^{10} \mathrm{Be}$ ages were excluded from the comparison, even when

215 they were excluded from analysis in the original publications.

216 After removal of samples with Chauvenet's criterion, 453 samples remained for

217 comparison within 102 model grid cells. To compare these ages with the model grid cells, all the

218 normalized grid cell PDFs in each of the 14 regions around theisland were summed (Figure 3, 4),

219 and the resulting PDF was compared to a histogram of model ice-retreat ages from that region

220 (Figure4).

\section{3. Results}

\section{$222 \quad$ 3.1Factor Analysis}

223 Results of the factor analysis are shown in Figures 5and 6c. Note that 49 ages from

224 Upernavik, Thule, Johannes V. Jensen Land, and Store Koldewey were excluded from the 225 analysis. We excluded these ages from the factor analysis because these areas have a very high

226 proportion of inherited ${ }^{10} \mathrm{Be}$, and have widely scattered ages (Larsen et al., 2016; Corbett et al.,

227 2013; 2015; Möller et al., 2010; Håkansson et al., 2007b). Factor analysis including all ages is

228 not significantly different from that presented here, but the factors explain a smaller proportion 
229 of the total variance. Six factors were required to explain $\sim 82 \%$ of the variance in the data, but

230 only four were retained to calculate orthogonal factors. These explain $\sim 72 \%$ of total variance

231 (Table3) and simplify the final analysis. The final factors are named from the age of maximum

232 probability, although it is important to note that each factor plot has significant structure beyond

233 the peak. In particular, the $12 \mathrm{ka}$ factor includes elevated values from $\sim 20 \mathrm{ka}$ to $11.5 \mathrm{ka}$. The 12

234 ka factor has its highest loadings in east Greenland (Figure 5a), with scattered grid cells in south

235 and west Greenland, most notably a cluster of grid cells on the west coast of the Sisimiut-

236 Kangerlussuaq region. In contrast, the $7.5 \mathrm{ka}$ grid cell is almost exclusively concentrated in west

237 Greenland, particularly in the eastern part of Sisimiut-Kangerlussuaq, Disko Bugt, and

238 Uummannaq. Both the $10 \mathrm{ka}$ and $11 \mathrm{ka}$ factors are relatively high across the island, although the

23910 ka factor is notably diminished in east Greenland.

240 The map of dominant factors shows a similar spatial pattern to the maps of individual

241 factors (Figure 5b). The dominant factor is defined here as the factor that explains the plurality of

242 variance in a grid cell. In east Greenland, the $12 \mathrm{ka}$ and $11 \mathrm{ka}$ factors dominate. West Greenland

243 is the only place where the $7.5 \mathrm{ka}$ is dominant. The $10 \mathrm{ka}$ factor is dominant in south Greenland,

244 in addition to scattered grid cells where the $11 \mathrm{ka}$ and $12 \mathrm{ka}$ ages are dominant. The average

245 communality of factors in all gridcells is 0.72 ; Figure $5 \mathrm{c}$ shows how this is distributed around the

246 island.

247 In contrast to the ${ }^{10} \mathrm{Be}$ ages, factor analysis of ${ }^{14} \mathrm{C}$ ages does not reveal a significant

248 spatial pattern. Figures 7 and 8 show the results of the factor analysis of ${ }^{14} \mathrm{C}$ ages. Ten factors

249 were required to explain $\sim 80 \%$ of the variance in the data (Table 4); we retained four factors for

250 the final analysis, which explain $\sim 62 \%$ of the total variance in the ${ }^{14} \mathrm{C}$ ages. The four factors each

251 have sharply defined peaks at $11.2 \mathrm{ka}, 10.2 \mathrm{ka}, 9.5 \mathrm{ka}$, and $8.3 \mathrm{ka}$ (Figure 7). However, none of 
252 the factors are heavily concentrated in any given region (Figure 8a), and there are no distinctive

253 patterns in the map of dominant factors (Figure 8b). In addition, communality in the factors is

254 significantly lower in the ${ }^{14} \mathrm{C}$ analysis (Figure $8 \mathrm{c}$ ), with average communality of 0.61.

$255 \quad 3.2$ Model-Data Comparisons

256 Figure 4shows that model-data fits vary between different regions in Greenland. The

257 closest match between the Huy 3 model and ${ }^{10} \mathrm{Be}$ ages is in west Greenland, where model retreat

258 ages overlap with ${ }^{10} \mathrm{Be}$ PDFs in Upernavik, Uummannaq, Disko Bugt, Sisimiut-Kangerlussuaq,

259 and Nuuk. In contrast, ${ }^{10} \mathrm{Be}$ PDFs consistently peak between 1 and 4 ka before modeledice

260 retreat occurs in north, east, and south Greenland, including Scoresby Sund, Kangerdlussuaq,

261 Sermilik, and Paamiut. In Bernstorffs and Narsarsuaq, the majority of modeledice retreat occurs

262 after the main peak in the ${ }^{10} \mathrm{Be}$ ages, although the lead in ${ }^{10} \mathrm{Be}$ ages is less pronounced than in the 263 rest of east and south Greenland.

\section{4. Discussion}

265 The ${ }^{10} \mathrm{Be}$ factoranalysis resultsdiffer significantly from the deglacial GrIS retreat scenario

266 outlined by Funder et al. (2011), which shows deglaciation from the outer coast after $\sim 11.7 \mathrm{ka}$ in

267 all locations except Scoresby Sund (deglaciated before $\sim 12.4 \mathrm{ka}$ ) and Kap Farvel at the southern

268 tip of Greenland (deglaciated by $\sim 14 \mathrm{ka}$ ). In our analysis, significant terrestrial ice retreat

269 occurred before $\sim 11.7 \mathrm{ka}$ at Scoresby Sund, Kangerdlussuaq, Sermilik, Nuuk, and Sisimiut-

270 Kangerlussuaq (Figure 5, 6c) (also further north at Johannes V. Jensen Land, and Store

271 Koldewey; Figure 4). Several studies from east Greenland investigated the behavior of local

272 glaciers and ice caps after the retreat of the ice sheet (Kelly et al., 2008; Levy et al., 2014;

273 Lowell et al., 2013); these minimum-limiting ages may suggest even earlier ice retreat of the

274 GrIS from the region, consistent with the overall spatial pattern observed here. This difference is 
275 expected as the Funder et al. (2011) reconstruction relied largely on minimum-limiting ${ }^{14} \mathrm{C}$ ages

276 that reflect the first establishment of soils, marine life and vegetation, which has an unknown lag

277 time behind ice-margin retreat.

278 In our factor analysis of ${ }^{14} \mathrm{C}$ ages, there is no evidence of the spatial pattern clearly 279 expressed in the ${ }^{10} \mathrm{Be}$ data. A direct comparison of the average ${ }^{10} \mathrm{Be}$ age and the oldest ${ }^{14} \mathrm{C}$ age in 280 the 27 gridcells containing both types of data shows that in most cases ${ }^{14} \mathrm{C}$ ages lag ${ }^{10} \mathrm{Be}$ ages, 281 but that the offset is not constant (Figure 9). ${ }^{10} \mathrm{Be}$ ages should directly date ice-margin retreat in 282 most cases (if inheritance, erosion, or later exhumation are not an issue), so the offset is likely 283 explained by the minimum-limiting nature of ${ }^{14} \mathrm{C}$ ages and an unknown time between ice retreat 284 and migration of vegetation to the site.

285 In contrast to the spatial Greenland deglaciation pattern identified by factor analysis, the 286 Huy3 model shows homogenous terrestrial ice-margin retreat. At a local scale, ${ }^{10} \mathrm{Be}$ ages 287 generally lead the Huy3 model results (Figure 4), with the exceptions of Uummannaq, Disko 288 Bugt, Nuuk and Sisimiut-Kangerlussuaq regions. Thispattern is particularly pronounced in east 289 Greenland, where there is generally little to no overlap of ${ }^{10} \mathrm{Be}$ PDFs and model histograms. The 290 majority of data used to calibrate the Huy3 model comes from west Greenland, particularly from 291 near Disko Bugt, so it is perhaps not surprising that this region shows the best data-model fit.

292 Discrepancies in other regions suggest some combination of model limitations (e.g., inaccurate

293 or missing forcings), bias in the data used to tune the model (e.g., use of ${ }^{14} \mathrm{C}$ ages), or systematic 294 biases in the ${ }^{10} \mathrm{Be}$ database. We note that the Huy3 model does have earlier periods of GrIS 295 retreat, as early as $\sim 16 \mathrm{ka}$ (Lecavalier et al., 2014), but this retreat is on the continental shelf and 296 not in regions constrained by ${ }^{10} \mathrm{Be}$ data. In the following sub-sections, we discuss three 297 hypotheses that could explain the spatial variability of terrestrial deglaciation and the data-model 
misfit.

\section{4.1 Elevation signal in ${ }^{10} \mathrm{Be}$ ages}

It is possible that the asynchronous retreat of the GrIS observed here is due to different

301 elevations of samples. East Greenland has higher mountains in general than south and west

302 Greenland, so the earlier deglaciation observed there could be a result of ice thinning, if the

303 samples were taken at higher elevations. However, there is no relationship between elevation and

$304{ }^{10} \mathrm{Be}$ ages in mostparts of the ice sheet(Table 5); the only two regions with an age-elevation

305 relationship significant at $\mathrm{p}<0.05$ are Disko Bugt and Johannes V. Jensen Land. The correlation

306 coefficient for Disko Bugt is negative, suggesting older ages are at lower elevations, and

307 therefore do not represent thinning of the ice sheet. There may be some thinning of the ice

308 recorded in cosmogenic ages in Johannes V. Jensen Land, however these were excluded from the

309 factor analysis and therefore cannot bias the analysis to thinning of the ice. We therefore believe

310 that most to all of the cosmogenic ages from the island record retreat of the ice margin, not the

311 GrIS thinning history.

$312 \quad 4.2^{10} \mathrm{Be}$ inheritance and post-exposure erosion

313 Systematic inheritance of ${ }^{10} \mathrm{Be}$ may account for the older ${ }^{10} \mathrm{Be}$ ages in some regions. Fast-

314 flowing, warm-based ice may remove at least $2 \mathrm{~m}$ of bedrock over a glacial cycle, removing

315 most inherited nuclides, but glacial erosivity is highly variable (e.g., Koppes and Montgomery,

316 2009), and surfaces beneath cold-based ice may be preserved for several glacial cycles (e.g.,

317 Davis et al., 2006; Stroeven et al., 2002; Corbett et al., 2011; 2013). Inheritance of ${ }^{10} \mathrm{Be}$ can be

318 identified in individual studies if sufficient samples are analyzed.Ideally, anomalous ${ }^{10} \mathrm{Be}$ ages

319 would be identified at the landform scale (e.g., at individual moraines), using quantitative

320 statistics with more than seven samples per landform collected (Putkonen and Swanson, 2003). 
321 Unfortunately, in most Greenland locations where ${ }^{10} \mathrm{Be}$ ages have been collected, too few

322 samples were collected to quantitatively identify outliers. Only 28 grid cells (27\%) have five or

323 more ${ }^{10} \mathrm{Be}$ samples, and only six grid cells $(6 \%)$ have 10 or more samples (Figure 10 ). This

324 presents a significant limitation for objectively identifying outliers. However, oura priori

325 exclusion should remove most old outliers; in the original literature,54 samples (out of 673) were

326 identified as old outliers younger than $21 \mathrm{ka}$, while 159 samples are older than $21 \mathrm{ka}$. In this

327 study, Chauvenet's criterion was applied at the model grid-cell scale where three or more

328 samples are present, which led to the exclusion of ten ages. This approach therefore leads to the

329 inclusion of ages that may have been excluded from original publications as outliers, but it also

330 represents an objective method for excluding outliers and forcing ${ }^{10} \mathrm{Be}$ data to match model

331 outputs.

332 One method for testing inheritance in ${ }^{10} \mathrm{Be}$ ages is to compare boulder and bedrock ${ }^{10} \mathrm{Be}$

333 ages, because erratic boulders are less likely to show significant inheritance (e.g., Briner et al.,

334 2006). Figure 11 shows that the majority of regions with both boulder and bedrock ages have

335 older bedrock ages than boulder ages. However, the Wilcoxon signed rank test for different

336 distributions shows significantly different ages $(\mathrm{p}<0.05)$ for only three regions: Sermilik,

337 Sisimiut-Kangerlussuaq, and Scoresby Sund (Table5). All of the coastal ages from Sermilik are

338 from bedrock with no adjacent boulder samples; the boulder samples come from further

339 inland.The "outliers" in the Sisimiut-Kangerlussuaq boulder distribution overlapping the bedrock

340 ages come from the coast. It is therefore difficult to ascertain if the older bedrock ages are a

341 result of systematic inheritance or geographic location in these cases. In the case of Scoresby

342 Sund, it is possible that the bedrock samples are influenced by inheritance. However, these

343 bedrock ages compose only $15 \%$ of all deglacial samples from Scoresby Sund, and therefore 
344 cannot account for the trends observed across the island.

345 Post-exposure erosion removes ${ }^{10} \mathrm{Be}$-rich surface layers, thereby biasing the samples

346 towards younger ages. There is some evidence of erosion in east Greenland (Håkansson et al.,

347 2011), although it has not been directly measured. If significant post-exposure erosion indeed

348 occurred in east Greenland, it could not account for the older exposure ages found there; on the

349 contrary, it would make the lead of east GrIS deglaciation even more pronounced.

\section{$350 \quad 4.3$ Model resolution and approximations}

351 A third hypothesis for the ${ }^{10} \mathrm{Be}$ data-model mismatch is that the ice-sheet model in its

352 present form is unable to capture high-resolution changes in the ice-margin reconstructed by ${ }^{10} \mathrm{Be}$

353 studies. Young and Briner (2015) noted such deficiencies in their review of Disko Bugt

354 deglaciation relative to the simulated deglaciation. ${ }^{10} \mathrm{Be}$ ages in Greenland are largely collected

355 from within and near fjord systems. These fjords are generally $3-5 \mathrm{~km}$ wide and rarely wider

356 than $10 \mathrm{~km}$, and therefore cannot be fully resolved in a model that runs at $20 \mathrm{~km}$ resolution. So,

357 while small-scale topographical features may significantly impact ice-margin behavior and be

358 recorded in the ${ }^{10} \mathrm{Be}$ record (e.g., Lane et al., 2013), this behavior will not be captured in a model

359 that does not resolve these topographic features.

360 The Huy3 model uses the shallow-ice approximation (Hutter, 1983; Simpson et al., 2009;

361 Lecavalier et al., 2014). This means that longitudinal stresses are ignored in the model, and basal

362 traction provides the only resistance to ice flow. This approximation works well for ice-sheet

363 interiors where longitudinal stresses are minimal, but breaks down at ice-sheet margins. In

364 particular, the approximation does not simulate marine-terminating outlet glaciers well (e.g.,

365 Dupont and Alley, 2005). ${ }^{10} \mathrm{Be}$ ages may therefore detect more rapid and earlier deglaciation in

366 fjords, while the model will reconstruct slower and therefore later deglaciation. 
Disko Bugt, Sisimiut-Kangerlussuaq and Nuuk are the only regions where ${ }^{10} \mathrm{Be}$ ages do

368 not significantly lead model deglaciation ages (Figure 4). The Sisimiut-Kangerlussuaq and

369 Nuuk ${ }^{10} \mathrm{Be}$ ages mostly measure terrestrial deglaciation in regions with more limited fjord

370 systems, so model resolution is less of an issue (Larsen et al., 2013; Winsor et al., 2015a). For

371 Disko Bugt, the data-model agreement likely also reflects the wealth of high precision relative

372 sea-level data from this locality (Simpson et al., 2009; Lecavalier et al., 2014).

373 Several further model limitations may explain the model-data discrepancies. When

374 comparing the modelled and observed present-day ice thickness distribution, the model over-

375 predicts ice thickness at the margin, which is also likely true for past GrIS geometries. Due to the

376 steep horizontal gradient in ice thickness at the margin, a small change in extent quickly

377 propagates to large ice thickness changes. Additionally, the adopted grid spacing poorly resolves

378 ice streams and outlet glaciers, which leads to an under-estimated discharge of ice at the margins,

379 thereby overestimating ice thickness at the margins. This highlights the need to improve the

380 model resolution, particularly in marginal areas withmore complex topography. The Huy3 model

381 is at present the highest resolution model reconstruction of the last Greenland deglaciation, but

382 the comparison discussed above indicates that there are still limitations within this model that

383 should be addressed in the future.

$384 \quad 4.4$ Climatic forcing

385 The largest source of uncertainty in the modeled ice-retreat reconstruction is the climate

386 forcing (e.g., Zweck and Huybrechts, 2005). The Huy3 model uses a climate forcing based on

387 the GRIP $\delta^{18} \mathrm{O}$ record scaled to temperature, which differs significantly from more accurate

388 recent temperature reconstructions of the deglacial interval using nitrogen isotopes (Figure 6b) 
389 (Buizert et al., 2014). Such differences between the estimated and actual climate forcing could 390 contribute to the data-model mismatch.

391 In addition, the ice-sheet model was not forced with regionally constrained temperatures,

392 which are especially necessary given the significance of surface mass balance in governing ice-

393 sheet extent. Marginal lakes have been recently used for climate reconstructions, which could

394 constrain the climate forcing at the ice margin (e.g., D'Andrea et al., 2011; Young et al., 2011a;

395 Axford et al., 2013; Carlson et al., 2014, Larsen et al., 2015), but these records do not extend

396 back into the deglacial period. These model weaknesses are outstanding issues in most standard

397 glacial cycle simulations (Huybrechts, 2002; Tarasov and Peltier, 2002; Simpson et al., 2009;

398 Tarasov et al., 2012) and have ramifications on the ice-sheet model reconstruction and on the

399 quality of the fit to the ${ }^{10} \mathrm{Be}$ ages.

400 The model does not explicitly incorporate the direct effects of ocean temperatures on ice-

401 sheet mass loss (Rignot et al., 2010). Where the glacier terminus is grounded below sealevel,

402 enhanced melting by warmer oceans can undercut the ice cliff, accelerating calving and ice

403 retreat (Kirkbride and Warren, 1997; van der Veen, 2002), in addition to direct melting. If a

404 floating ice shelf is present, warming ocean waters can lead to enhanced basal melting of the

405 shelf, reducing buttressing effects and permitting faster flow and thinning of the ice (Schoof,

406 2007; Dupont and Alley, 2005; Shepherd et al., 2004). In addition, collapse of floating ice

407 shelves can cause rapid acceleration and retreat of outlet glaciers feeding into the former ice

408 shelf (e.g., Scambos et al., 2004; Marcott et al., 2011).

409 The lack of an ocean forcing can explain the discrepancy in areas such as southeast and

410 south Greenland, where marine records show a general warming trend from $\sim 15$ ka to peak

411 warmth $\sim 10$ ka (Figure 6a) (Williams, 1993; Solignac et al., 2004; Jennings et al., 2006; Winsor 
412 et al., 2012). This warming continues through the Younger Dryas cold period, and is concurrent

413 with increased sediment discharge from southeast Greenland (Carlson et al., 2008; Colville et al.,

414 2011) and southern Greenland (Winsor et al., 2015b). The warming trend is also concurrent with

415 the increase in the varimax factor scores for the $12 \mathrm{ka}$ factor, which is most concentrated in east

416 Greenland and northern southeast Greenland (Figure 6b).Peak ocean warmth occurs between

417 approximately $12 \mathrm{ka}$ and $9.5 \mathrm{ka}$, encompassing the maximum values of all factors except the 7.5

418 ka factor (Figure 6c). We therefore hypothesize that south and east GrIS margin retreat from the

419 shelf and into fjords prior to modeled margin retreat could reflect this additional climate forcing

420 that was excluded in the Huy3 model. Marine records from west Greenland show cold glacial

421 conditions persisting until 7-8 ka near the end of west GrIS retreat and the peak in the $7.5 \mathrm{ka}$

422 factor (Figure 6a, 6c)(Jennings et al., 2014), possibly explaining the agreement between ice-

423 sheet-modeled deglaciation and ${ }^{10} \mathrm{Be}$-observed deglaciation as the main climate forcing would be

424 atmospheric changes that were included in the ice-sheet model.

\section{5. Conclusions}

426 Our analyses of the ${ }^{10} \mathrm{Be}$ database highlights several important deglacial features of the

427 GrIS. While the majority of terrestrial ice retreat likely occurred following the Younger Dryas in

428 the early Holocene, it was spatially variable, with factor analysis indicating it can be explained

429 by the combination of 4 orthogonal factors. In general, east Greenland is best explained by the 12

$430 \mathrm{ka}$ and $11 \mathrm{ka}$ factors, south Greenland is best explained by the $11 \mathrm{ka}$ and $10 \mathrm{ka}$ factors, and west

431 Greenland is best explained by the $10 \mathrm{ka}$ and $7.5 \mathrm{ka}$ factors. These factors define a progression of

432 GrIS retreat from east to south to west Greenland. This pattern is not observed in a similar

433 analysis of ${ }^{14} \mathrm{C}$ ages, and theHuy3 ice sheet model reconstruction does not simulate the earlier

434 onset of GrIS retreat in east and south Greenland, where it lags the ${ }^{10} \mathrm{Be}$ ages. This could be 
435 partly due to the minimum-limiting nature of ${ }^{14} \mathrm{C}$ ages and the resolution of the model, which is

436 too coarse to resolve the many fjord systems in these regions, limiting ice-ocean interactions.

437 Also, the Huy3 modeldoes not include any direct influence of ocean warming on mass loss, and

438 east to south GrIS retreat is concurrent with general surface and subsurface ocean warming

439 suggesting a potential causal linkage. Conversely, the model captures the deglacial pattern of

440 west GrIS retreat, where fjord systems are more limited (with the exception of Disko Bugt) and

441 where ocean temperatures did not begin to warm until near the end of the deglaciation. As such,

442 the simpler atmospheric model forcing and ice-sheet model resolutionwere sufficient to simulate

443 deglaciation in this region.

$444 \quad$ Future ice-sheet modeling efforts should focus on improving model resolution to resolve

445 the complex topography of Greenland and include interaction with ocean waters. Specifically,

446 the model would benefit from increased resolution, dynamics derived from geophysical

447 processes, and the inclusion of ice-ocean interactions using ocean temperature forcing informed

448 by ocean proxy records. As advances in modeling techniques and resolution continue, the ${ }^{10} \mathrm{Be}$

449 database presented here will continue to be a useful tool for developing and validating models,

450 particularly as new data continue to be collected and published.

\section{Acknowledgements}

452 Funding for this research was provided by the National Science Foundation (PLR-1418074 to 453 AEC and PLR-1417886 to RD), and an Oregon State University Provost Fellowship and a 454 National Science Foundation Graduate Fellowship to GS. Inspiring discussions from the 455 PAGES/INQUA working group PALeo constraints on SEA level rise 2 (PALSEA2) are 456 acknowledged.Two anonymous reviewers, Vincent Rinterknecht and Nicolaj Larsen helped 457 improve earlier versions of this paper. 


\section{Table Captions}

459 Table 1: Description of all published papers with ${ }^{10} \mathrm{Be}$ ages in Greenland, with region of 460 publication and number of ${ }^{10} \mathrm{Be}$ samples. Full references in reference list.

461 Table 2: Description of all published papers with ${ }^{14} \mathrm{C}$ ages in Greenland, with number of ${ }^{14} \mathrm{C}$ 462 samples. Full references in reference list.

463 Table 3: Eigenvalues for initial factors in ${ }^{10} \mathrm{Be} \mathrm{Q}$-mode analysis.

464 Table 4: Eigenvalues for initial factors in ${ }^{14} \mathrm{C}$ Q-mode analysis.

465 Table 5: Pearson's correlation coefficient and $\mathrm{p}$ values for ${ }^{10} \mathrm{Be}$ age-elevation relationships for 466 the different regions of Greenland.

467 Table 6: Results of Wilcoxon signed-rank test for bedrock and boulder ages.

\section{Figure Captions}

469 Figure 1: Map of all published ${ }^{10} \mathrm{Be}$ ages from Greenland. Individual ${ }^{10} \mathrm{Be}$ ages are represented 470 by dots, with colors corresponding to the age of the sample. Text colors correspond to the

471 broader region (identified in all capitals) each individual location is assigned to by factor 472 analysis.

473 Figure 2: Map of all published ${ }^{14} \mathrm{C}$ ages from Greenland. Individual ${ }^{14} \mathrm{C}$ ages are represented by 474 diamonds, with colors corresponding to the age of the sample (note the scale in this color bar is 475 different from Figure 1).

476 Figure 3: Schematic diagram showing method for calculating normalized grid cell PDFs for

477 factor analysis, and regional PDFs for comparison with the Huy3 ice sheet model reconstruction.

478 The reader is referred to the text for a full description of the Figure. 
479 Figure 4: Summed grid cell PDFs of deglacial ${ }^{10} \mathrm{Be}$ ages in Greenland, compared with deglacial 480 ages in the Huy3 model.Each region is labeled with the number of samples indicated. Gray 481 shading is the PDF while the green bars are the model results.

482 Figure 5: ${ }^{10} \mathrm{Be}$ Factor Analysis(a)Factor loadings in individual grid cells with the factors noted 483 by the peak of that factor; height of the bar denotes the strength of each factor in that cell. (b)

484 Dominant factor in each grid cell, defined as the factor with the highest loading in that cell; 485 colors correspond to (a). (c) Communality of factors for each grid cell, which indicates how 486 much of the variance of each grid cell is explained by the sum of the four factors.

487 Figure 6: Comparison of ${ }^{10} \mathrm{Be}$ factors with climatic forcings. (a) $\mathrm{Mg} / \mathrm{Ca}$-derived subsurface 488 water temperatures at Eirik Drift, south Greenland (points), with 3-point running average (line) 489 (MD99-2227, Winsor et al., 2012) and percentage of warm-water foraminifera in Disko Bugt 490 (orange) (HU2008029-070CC, Jennings et al., 2014); (b) Huy3 temperature forcing (red;GRIP 491 ice core, Lecavalier et al., 2014) and reconstructed central Greenland air surface temperatures 492 (blue;GISP2 ice core, Buizert et al., 2014);(c) ${ }^{10}$ Be varimax factor loadings (this study), with 493 colors representing different factors labeled by their peak value. Inset map shows approximate 494 locations of ice and ocean core records.

495 Figure 7: ${ }^{14} \mathrm{C}$ varimax factor loadings, with colors representing different factors labeled by their 496 peak value.

497 Figure 8: ${ }^{14} \mathrm{C}$ Factor Analysis(a)Factor loadings in individual grid cells with the factors noted by 498 the peak of that factor; height of the bar denotes the strength of each factor in that cell. (b) 499 Dominant factor in each grid cell, defined as the factor with the highest loading in that cell; 500 colors correspond to (a). (c) Communality of factors for each grid cell, which indicates how 501 much of the variance of each grid cell is explained by the sum of the four factors. 
502 Figure 9: Comparison of average ${ }^{10} \mathrm{Be}$ and oldest ${ }^{14} \mathrm{C}$ ages in the same grid cell. Uncertainty bars

503 for ${ }^{14} \mathrm{C}$ ages reflect 1-sigma uncertainty for the sample; uncertainty bars for ${ }^{10} \mathrm{Be}$ ages reflect

504 standard error of ${ }^{10} \mathrm{Be}$ ages in the grid cell (if 3 or more samples are present) or average

505 analytical uncertainty of ages (if fewer than 3 samples are present).

506 Figure 10: Histogram showing the number of model grid cells with a given number of ${ }^{10} \mathrm{Be}$

507 samples.

508 Figure 11: Comparison via whisker plots of bedrock (blue) and boulder (red) ages for all regions

509 in Greenland (labeled) with both bedrockand boulderages. The box shows the one sigma range

510 with the bar in the middle being the median age while the lines (whiskers) denote the two sigma

511 range of the samples.

\section{References Cited:}

513 Alexanderson, H., Håkansson, L., 2014. Coastal glaciers advanced onto Jameson Land, East

514 Greenland during the late glacial-early Holocene Milne Land Stade. Polar Research, 33.

$515 \quad$ http://dx.doi.org/10.3402/polar.v33.20313.

516 Axford, Y., Losee, S., Briner, J.P., Francis, D.R., Langdon, P.G., Walker, I.R., 2013. Holocene

517 temperature history at the western Greenland Ice Sheet margin reconstructed from lake

$518 \quad$ sediments. Quaternary Science Reviews 59, 87-100.

519 Balco, G., Stone, J.O., Lifton, N.A., Dunai, T.J., 2008. A complete and easily accessible means

520 of calculating surface exposure ages or erosion rates from $\mathrm{Be}-10$ and $\mathrm{Al}-26$

521 measurements. Quaternary Geochronology 3, 174-195.

522 Balco, G., Briner, J., Finkel, R.C., Rayburn, J.A., Ridge, J.C., Schaefer, J.M., 2009. Regional

523 beryllium-10 production rate calibration for northeastern North America. Quaternary

524 Geochronology 4, 93-107. 
525 Balco, G., 2011. Contributions and unrealized potential contributions of cosmogenic-nuclide 526 exposure dating to glacier chronology, 1990-2010. Quaternary Science Reviews 30, 3-27.

527 Bennike, O., 2008. An early Holocene Greenland whale from Melville Bugt, Greenland. $528 \quad$ Quaternary Research 69, 72-76.

529 Bennike, O., Björck, S., 2002. Chronology of the last recession of the Greenland Ice Sheet. $530 \quad$ Journal of Quaternary Science 17, 211-219.

531 Bennike, O., Björck, S., Lambeck, K., 2002. Estimates of South Greenland late-glacial ice limits 532 from a new relative sea level curve. Earth and Planetary Science Letters 197, 171-186.

533 Bennike, O., Wagner, B., 2012. Deglaciation chronology, sea-level changes and environmental 534 changes from Holocene lake sediments of Germania Havn Sø, Sabine Ø, northeast $535 \quad$ Greenland. Quaternary Research 78, 103-109.

536 Bennike, O., Wagner, B., Righter, A., 2011. Relative sea level changes during the Holocene in 537 the Sisimiut area, south-western Greenland. Journal of Quaternary Science, 26, 353-361.

538 Briner, J.P., Håkansson, L., Bennike, O., 2013. The deglaciation and neoglaciation of Upernavik 539 Isstrøm, Greenland. Quaternary Research 80, 459-467.

540 Briner, J.P., Kaufman, D.S., Bennike, O., Kosnik, M.A., 2014. Amino acid ratios in reworked 541 marine bivalve shells constrain Greenland Ice Sheet history during the Holocene. $542 \quad$ Geology. http://dx.doi.org/10.1130/G34843.1

543 Briner, J.P., Miller, G.H., Davis, P.T., Finkel, R.C., 2006. Cosmogenic radionuclides from fiord 544 landscapes support differential erosion by overriding ice sheets. Geological Society of $545 \quad$ America Bulletin 118, 406-420. 
546 Briner, J.P., Stewart, H.A.M., Young, N.E., Phillipps, W., Losee, S., 2010 Using proglacial-

547 threshold lakes to constrain fluctuations of the Jakobshavn Isbrae ice margin, western $548 \quad$ Greenland, during the Holocene. Quaternary Science Reviews 29, 3861-3874.

549 Buizert, C., Gkinis, V., Severinghaus, J.P., He, F., Lecavalier, B.S., Kindler, P., Leuenberger, 550 M., Carlson, A.E., Vinther, B., Masson-Delmotte, V., White, J.W.C., Liu, Z., Otto551 Bleisner, B., Brook, E.J., 2014. Greenland temperature responses to climate forcing 552 during the last deglaciation. Science 345, 1177-1180.

553 Carlson, A.E., Stoner, J.S., Donnelly, J.P., Hillaire-Marcel, C., 2008. Response of the southern 554 Greenland Ice Sheet during the last two deglaciations. Geology 36, 359-362.

555 Carlson, A.E., Winsor, K., Ullman, D.J., Brook, E.J., Rood, D.H., Axford, Y., LeGrande, A.N., 556 Anslow, F.S., Sinclair, G., 2014. Earliest Holocene south Greenland ice sheet retreat $557 \quad$ within its late Holocene extent. Geophysical Research Letters 41, 5514-5521.

558 Clark, P.U., Dyke, A.S., Shakun, J.D., Carlson, A.E., Clark, J., Wohlfarth, B., Hostetler, S.W., 559 Mitrovica, J.X., McCabe, A.M., 2009. The Last Glacial Maximum. Science 325, 710$560 \quad 714$.

561 Clark, P.U., Shakun, J.D., Baker, P.A., Bartlein, P.J., Brewer, S., Brook, E., Carlson, A.E., 562 Cheng, H., Kaufman, D.S., Liu, Z., Marchitto, T.M., Mix, A.C., Morrill, C., Otto563 Bleisner, B.L., Pahnke, K., Russell, J.M., Whitlock, C., Adkins, J.F., Blois, J.L., Clark, J., 564 Colman, S.M., Curry, W.B., Flower, B.P., He, F., Johnson, T.C., Lynch-Stieglitz, J., 565 Markgraf, V., McManus, J., Mitrovica, J.X., Moreno, P.I., Williams, J.W., 2012. Global 566 climate evolution during the last deglaciation. Proc. Natl. Acad. Sciences 109, 567 http://dx.doi.org/10.1073/pnas.1116619109. 
568 Colville, E.J., Carlson, A.E., Beard, B.L., Hatfield, R.G., Stoner, J.S., Reyes, A.V., Ullman, D.J.,

569 2011. Sr-Nd-Pb isotope evidence for ice-sheet presence on Southern Greenland during 570 the last interglacial. Science 333, 620-623.

571 Corbett, L.B., Bierman, P.R., Graly, J.A., Neumann, T.A., Rood, D.H. 2013. Constraining 572 landscape history and glacial erosivity using paired cosmogenic nuclides in Upernavik, 573 northwest Greenland. Geological Society of America Bulletin 125, 1539-1553.

574 Corbett, L.B., Young, N.E., Bierman, P.R. Briner, J.P., Neumann, T.A., Rood, D.H., Graly, J.A., 575 2011. Paired bedrock and boulder ${ }^{10} \mathrm{Be}$ concentrations resulting from early Holocene ice 576 retreat near Jakobshavn Isfjord, western Greenland. Quaternary Science Reviews 30, $577 \quad 1739-1747$.

578 Corbett, L.B., Bierman, P.R., Everett Lasher, G., Rood, D.H., 2015. Landscape chronology and 579 glacial history in Thule, northwest Greenland. Quaternary Science Reviews 109, 57-67.

580 Cronauer, S.L., Briner, J.P., Kelley, S.E., Zimmerman, S.R.H., Morlighem, M., 2015. ${ }^{10}$ Be 581 dating reveals early-middle Holocene age of the Drygalski Moraines in central West $582 \quad$ Greenland. Quaternary Science Reviews, in press.

583 D’Andrea, W.J., Huang, Y., Fritz, S.C., Anderson, N.J., 2011. Abrupt Holocene climate change 584 as an important factor for human migration in West Greenland. Proceedings of the $585 \quad$ National Academy of Sciences, doi: 10.1073/pnas.1101708108.

586 Davis, P.T., Briner, J.P., Coulthard, R.D., Finkel, R.W., Miller, G.H., 2006. Preservation of $587 \quad$ Arctic landscapes overridden by cold-based ice sheets. Quaternary Research 65, 156$588 \quad 163$.

589 Dupont, T.K., Alley, R.B., 2005. Assessment of the importance of ice-shelf buttressing to ice $590 \quad$ sheet flow. Geophysical Research Letters. doi: 10.1029/2004GL022024. 
591 Dyke, A.S., 2004. An outline of North American deglaciation with emphasis on central and 592 northern Canada. In Ehlers, J., and Gibbard, P.L. (eds), Quaternary Glaciations-Extent and chronology. Part II: North America. Amsterdam: Elsevier.

594 Dyke, L.M., Hughes, A.L.C., Murray, T., Heimstra, J.F., Andresen, C.S., Rodés, Á., 2014. Evidence for the asynchronous retreat of large outlet glaciers in southeast Greenland at the end of the last glaciation. Quaternary Science Reviews 99, 244-259.

597 Farrell, W.E., Clark, J.A., 1976. On postglacial sea level. Geophysical Journal of the Royal Astronomical Society 46, 647-667.

599 Fredskild, B., 1973. Studies in vegetational history of Greenland. Meddelelser om Grønland 600 Geoscience 11, 24 pp.

601 Funder, S., 1979. The Quaternary geology of the Narssaq area, South Greenland. Rapport 602 Grønlands Geologiske Undersøgelse 86, 24 pp.

603 Funder, S., Kjeldsen, K.K., Kjær, K.H., Ó Cofaigh, C., 2011. The Greenland Ice Sheet during the 604 past 300,000 years: a review. In Ehlers, J., Gibbard, P.L., and Hughes, P.D., eds. 605 Quaternary Glaciations-extent and chronology. Amsterdam: Elsevier.

Håkansson, L., Briner, J.P., Aldahan, A., Possnert, G., 2011. ${ }^{10}$ Be data from meltwater channels suggest that Jameson Land, east Greenland, was ice-covered during the last glacial maximum. Quaternary Research 76, 452-459.

609 Håkansson, L., Briner, J., Alexanderson, H., Aldahan, A., Possnert, G., 2007a. ${ }^{10}$ Be ages from 610 central east Greenland constrain the extent of the Greenland ice sheet during the Last 611 Glacial Maximum. Quaternary Science Reviews 26, 2316-2321.

612 Håkansson, L., Briner, J.P., Andresen, C.S., Thomas, E.K., Bennike, O., 2014. Slow retreat of a 613 land based sector of the West Greenland Ice Sheet during the Holocene Thermal 
Maximum: evidence from threshold lakes at Paakitsoq. Quaternary Science Reviews 98, 74-83.

616 Håkansson, L., Graf, A., Strasky, S., Ivy-Ochs, S., Kubik, P.W., Hjort, C., Schlüchter, C., $2007 b$. 617 Cosmogenic ${ }^{10}$ Be-ages from the Store Koldewey Island, NE Greenland. Geografiska $618 \quad$ Annaler 89, 195-202.

619 Håkansson, L., Hjort, H., Möller, P., Briner, J.P., Aldahan, A., Possnert, G. 2009. Late 620 Pleistocene glacial history of Jameson Land, central East Greenland, derived from cosmogenic ${ }^{10} \mathrm{Be}$ and ${ }^{26} \mathrm{Al}$ exposure dating. Boreas 38, 244-260.

622 Hogan, K.A., Ó Cofaigh, C., Jennings, A.E., Dowdeswell, J.A., Heimstra, J.F., 2016. Deglaciation of a major palaeo-ice stream in Disko Trough, West Greenland. Quaternary Science Reviews, in press. http://dx.doi.org/ 10.1016/j.quascirev.2016.01.018.

625 Hughes, A.L.C., Rainsley, E., Murray, T., Fogwill, C.J., Schnabel, C., Xu, S., 2012. Rapid 626 response of Helheim Glacier, southeast Greenland, to early Holocene climate warming. Geology 40, 427-430.

628 Hutter, K., 1983. Theoretical Glaciology: Material science of ice and the mechanics of glaciers and ice sheets. Norwell, MA: Kluwer Academic.

630 Huybrechts, P., 2002. Sea-level changes at the LGM from ice-dynamic reconstructions of the 631 Greenland and Antarctic ice sheets during the glacial cycles. Quaternary Science Reviews 632 $21,203-231$.

633 Imbrie, J., and Kipp, N.G., 1971. A new micropaleontological method for quantitative 634 paleoclimatology: application to a late Pleistocene Caribbean core. In Turekian, K.K., ed. 635 The Late Cenozoic Glacial Ages. New Haven: Yale University Press 
636 Imbrie, J., and van Andel, T.H., 1964. Vector analysis of heavy-mineral data. Geological Soceity $637 \quad$ of America Bulletin 75, 1131-1156.

638 Jennings, A., Andrews, J., Wilson, L., 2011. Holocene environmental evolution of the SE 639 Greenland Shelf North and South of the Denmark Strait: Irminger and East Greenland $640 \quad$ current interactions. Quaternary Science Reviews 30, 980-998.

641 Jennings, A.E., Hald, M., Smith, M., Andrews, J.T., 2006. Freshwater forcing from the 642 Greenland Ice Sheet during the Younger Dryas: evidence from southeastern Greenland 643 shelf cores. Quaternary Science Reviews 25, 282-298.

644 Jennings, A.E., Walton, M.E., Ó Cofaigh, C., Kilfeather A., Andrews, J.T., Ortiz, J.D., De 645 Vernal, A., Dowdeswell, J.A., 2014. Paleoenvironments during the Younger Dryas-Early 646 Holocene retreat of the Greenland Ice Sheet from outer Disko Trough, central west 647 Greenland. Journal of Quaternary Science 29, 27-40.

648 Kelly, M., 1974. The marine limit in Julianhab district, south Greenland, and its isostatic 649 implications. In Blundel, D.J., ed: Crustal Structure of the Gardar Rift, South Greenland: Report on Fieldwork 1973. Lancaster: Department of Environmental Sciences

651 Kelly, M., 1975 A note on the implications of two radiocarbon dated samples from Qaleraglit 652

653 Kelley, S.E., Briner, J.P., Young, N.E., 2013. Rapid ice retreat in Disko Bugt supported by ${ }^{10}$ Be 654 dating of the last recession of the western Greenland Ice Sheet. Quaternary Science $655 \quad$ Reviews 82, 13-22.

656 Kelley, S.E., Briner, J.P., Young, N.E., Babonis, G.S., Csatho, B., 2012. Maximum late 657 Holocene extent of the western Greenland Ice Sheet during the late $20^{\text {th }}$ Century. $658 \quad$ Quaternary Science Reviews 56, 89-98. 
659 Kelley, S.E.,Briner, J.P. and Zimmerman, S., 2015. The influence of ice marginal setting on 660 early Holocene retreat rates in central West Greenland. Journal of Quaternary Science, v. 66130, p. $271-280$

662 Kelly, M.A., Lowell, T.V., Hall, B.L., Schaefer, J.M., Finkel, R.C., Goehring, B.M., Alley, R.B., 663 Denton, G.H., 2008. A ${ }^{10}$ Be chronology of late glacial and Holocene mountain glaciation 664 in the Scoresby Sund region, east Greenland: implications for seasonality during 665 lateglacial time. Quaternary Science Reviews 27, 2273-2282.

666 Kirkbride, M.P., Warren, C.R., 1997. Calving processes at a grounded ice cliff. Annals of 667 Glaciology 24, 116-121.

668 Koppes, M.N., and Montgomery, D.R., 2009. The relative efficacy of fluvial and glacial erosion 669 over modern to orogenic timescales. Nature Geoscience 2, 644-647.

670 Kuijpers, A., Troelstra, S.R., Prins, M.A., Linthout, K., Akhmetzhanov, A., Bouryak, S., 671 Bachmann, M.F., Lassen, S., Rasmussen, S., Jensen, J.B., 2003. Late Quaternary 672 sedimentary processes and ocean circulation changes at the Southeast Greenland margin. $673 \quad$ Marine Geology 195, 109-129.

674 Lane, T.P., Roberts, D.H., Rea, B.R., Ó Cofaigh, C., Vieli, A., Rodés, A., 2013. Controls upon 675 the Last Glacial Maximum deglaciation of the northern Uummannaq Ice Stream System, 676 West Greenland. Quaternary Science Reviews 92, 324-344.

677 Larsen, N.K., Funder, S., Kjær, K.H., Kjeldsen, K.K., Knudsen, M.F., Linge, H., 2013. Rapid 678 early Holocene ice retreat in West Greenland. Quaternary Science Reviews 92, 310-323.

679 Larsen, N.K., Funder, S., Linge, H., Möller, P., Schomacker, A., Fabel, D., Xu, S., Kjær, K.H., 680 2016. A Younger Dryas re-advance of local glaciers in north Greenland. Quaternary 681 Science Reviews, doi: 10.1016/j.quascirev.2015.10.036. 
682 Larsen, N.K., Kjær, K.H., Lecavalier, B., Bjørk, A.A., Colding, S., Huybrechts, P., Jakobsen, 683 K.E., Kjeldsen, K.K., Knudsen, K.-L., Odgaard, B.V., Olsen, J., 2015. The response of 684 the southern Greenland ice sheet to the Holocene thermal maximum. Geology, doi: $685 \quad 10.1130 / \mathrm{G} 36476.1$.

686 Larsen, N.K., Kjær, K.H., Olsen, J., Funder, S., Kjeldsen, K.K., Nørgaard-Pedersen, N., 2011. 687 Restricted impact of Holocene climate variations on the southern Greenland Ice Sheet. $688 \quad$ Quaternary Science Reviews 3171-3180

689 Lecavalier, B.S., Milne, G.A.. Simpson, M.J.R., Wake, L., Huybrechts, P., Tarasov, L., Kjeldsen, 690 K.K., Funder, S., Long, A.J., Woodroffe, S., Dyke, A.S., Larsen, N.K., 2014 A model of 691 $692 \quad$ Ice Extent. Quaternary Science Reviews 102, 54-84.

693 Levy, L.B., Kelly, M.A., Howley, J.A., Virginia, R.A., 2012. Age of the Ørkendalen moraines, 694 Kangerlussuaq, Greenland: constraints on the extent of the southwestern margin of the 695 Greenland Ice Sheet during the Holocene. Quaternary Science Reviews 52, 1-5.

696 Levy, L.B., Kelly, M.A., Lowell, T.V., Hall, B.L., Hempel, L.A., Honsaker, W.M., Lusas, A.R., 697 Howley, J.A., Axford, Y.L., 2014. Holocene fluctuations of Bregne ice cap, Scoresby 698 Sund, east Greenland: a proxy for climate along the Greenland Ice Sheet margin. 699 Quaternary Science Reviews 92, 356-368.

700 Lloyd, J.M., Park, L.A., Kuijpers, A., Moros, M., 2005. Early Holocene palaeoceanography and 701 detailed chronology of Disko Bugt, West Greenland. Quaternary Science Reviews 24, $702 \quad 1741-1755$. 
703 Lloyd, J., M. Moros, K. Perner, R. J. Telford, A. Kuijpers, E. Jansen, McCarthy, D., 2011. A 100

$704 \quad \mathrm{yr}$ record of ocean temperature control on the stability of Jakobshavn Isbrae, West $705 \quad$ Greenland. Geology 39, 867-870.

706 Long, A.J., Roberts, D.H., Simpson, M.J.R., Dawson, S., Milne, G.A., Huybrechts, P., 2008.

707 Late Weichselian relative sea-level changes and ice sheet history in southeast Greenland. $708 \quad$ Earth and Planetary Science Letters 272, 8-18.

709 Long, A.J., Woodroffe, S.A., Dawson, S., Roberts, D.H., Bryant, C.L., 2009. Late Holocene 710 relative sea level rise and the Neoglacial history of the Greenland ice sheet. Journal of $711 \quad$ Quaternary Science 24, 345-359.

712 Lowell, T.V., Hall, B.L., Kelly, M.A., Bennike, O., Lusas, A.R., Honsaker, W., Smith, C.A.,

713 Levy, L.B., Travis, S., Denton, G.H., 2013. Late Holocene expansion of Istorvet ice cap,

714 Liverpool Land, east Greenland. Quaternary Science Reviews 63, 128-140.

715 Marcott, S.A., Clark, P.U., Padman, L., Klinkhammer, G.P., Springer, S., Liu, Z., Otto-Bliesner,

716 B.L., Carlson, A.E., Ungerer, A., Padman, J., He, F., Cheng, J., Schmittner, A., 2011. Ice-

717 shelf collapse from subsurface warming as a trigger for Heinrich events. Proceedings of

718 the National Academy of Sciences, doi: 10.1073/pnas.1104772108.

719 Massa, C., Perren, B.B., Gauthier, É, Bichet, V., Petit, C., Richard, H., 2012. A multiproxy 720 evaluation of Holocene environmental change from Lake Igaliku, South Greenland. $721 \quad$ Journal of Paleolimnology 48, 241-258.

722 Milne, G.A., Shennan, I., 2013. Isostasy: glaciation induced sea-level change. Encyclopedia of 723 Quaternary Science 3, 452-459.

724 Mix, A.C., et al., 1999. Foraminiferal faunal estimates of paleotemperature: Circumventing the 725 no-analog problem yields cool ice age tropics. Paleoceanography 14, 350-359 
726 Möller, P., Larsen, N.K., Kjær, K.H., Funder, S., Schomacker, A., Linge, H., Fabel, D., 2010.

727 Early to middle Holocene valley glaciations on northernmost Greenland. Quaternary $728 \quad$ Science Reviews 29, 3379-3398.

729 Nelson, A., Bierman, P.R., Shakun, J.D., Rood, D.H., 2014. Using in situ cosmogenic ${ }^{10}$ Be to 730 identify the source of sediment leaving Greenland. Earth Surface Processes and $731 \quad$ Landforms. 39, 1087-1100.

732 Nøgaard-Pedersen, N., and Mikkelsen, N., 2009. 8000 year marine record of climate variability 733

734 Ó Cofaigh, C., Dowdeswell, J.A., Jennings, A.E., Hogan, K.A., Kilfeather, A., Heimstra, J.F., 735 Noormets, R., Evans, J., McCarthy, D.J., Andrews, J.T., Lloyd, J.M., Moros, M., An 736 extensive and dynamic ice sheet on the West Greenland shelf during the last glacial 737 cycle. Geology. http://dx.doi.org/10.1130/G33759.1

738

739 Olsen, J., Kjær, K.H., Funder, S., Larsen, N.K., Ludikova, A., 2011. High-Arctic climate 740 conditions for the last 7000 years inferred from multi-proxy analysis of the Bliss Lake 741 record, North Greenland. Journal of Quaternary Science. $742 \quad$ http://dx.doi.org/10.1002/jqs. 1548

743 Perner, K., Moros, M., Jennings, A., Lloyd, J.M., Knudsen, K.L., 2013. Holocene 744 palaeoceanographic evolution off West Greenland. The Holocene 23, 374-387.

745 Pisias, N.G., Murray, R.W., Scudder, R.P., 2013. Multivariate statistical analysis and partitioning 746 of sedimentary geochemical data sets : General principles and specific MATLAB scripts.

747 Geochemistry Geophysics Geosystems 14, 4015-4020 
748 Putkonen, J., Swanson, T., 2003. Accuracy of cosmogenic ages for moraines. Quaternary 749 Research 59, http://dx.doi.org/10.1016/S0033-5894(03)00006-1.

750 Rignot, E., Koppes, M., Velicogna, I., 2010. Rapid submarine melting of the calving faces of $751 \quad$ West Greenland glaciers. Nature Geoscience 3, 187-191.

752 Rinterknecht, V., Gorokhovich, Y., Schaefer, J., Caffee, M., 2009. Preliminary ${ }^{10}$ Be chronology

753 for the last deglaciation of the western margin of the Greenland Ice Sheet. Journal of $754 \quad$ Quaternary Science 24, 270-278.

755 Rinterknecht, V., Jomelli, V., Brunstein, D., Favier, V., Masson-Delmotte, V., Bourlès, D.,

756 Leanni, L., Schläppy, R., 2014. Unstable ice stream in Greenland during the Younger $757 \quad$ Dryas cold event. Geology, http://dx.doi.org/10.1130/G35929.1.

758 Roberts, D.H., Long, A.J., Schnabel, C., Davies, B.J., Xu, S., Simpson, M.J.R., Huybrechts, P., 759 2009. Ice sheet extent and early deglacial history of the southwestern sector of the $760 \quad$ Greenland Ice Sheet. Quaternary Science Reviews 28, 2760-2773.

761 Roberts, D.H., Long, A.J., Schnabel, C., Freeman, S., Simpson, M.J.R., 2008. The deglacial 762 history of southeast sector of the Greenland Ice Sheet during the Last Glacial Maximum. 763 Quaternary Science Reviews 27, 1505-1516.

764 Roberts, D.H., Rea, B.R., Lane, T.P., Schnabel, C., Rodès, A., 2013. New constraints on 765 Greenland ice sheet dynamics during the last glacial cycle: evidence from the 766 Uummannaq ice stream system. Journal of Geophysical Research: Earth Surface 118, 1$767 \quad 23$.

768 Scambos, T.A., Bohlander, J.A., Shuman, C.A., Skvarca, P., 2004. Glacier acceleration and 769 thinning after ice shelf collapse in the Larsen B embayment, Antarctica. Geophysical $770 \quad$ Research Letters 31, http://dx.doi.org/10.1029/2004GL020670. 
771 Schoof, C., 2007. Ice sheet grounding line dynamics: steady states, stability, and hysteresis. $772 \quad$ Journal of Geophysical Research 112, doi: 10.1029/2006JF000664.

773 Shakun, J., Carlson, A.E., 2010. A global perspective on Last Glacial Maximum to Holocene $774 \quad$ climate change. Quaternary Science Reviews 29, 1801-1816.

775 Shepherd, A., Wingham, D., Rignot, E., 2004. Warm ocean is eroding West Antarctic Ice Sheet. 776 Geophysical Research Letters 31, http://dx.doi.org/10.1029/2004GL021106.

777 Sheldon, C., Jennings, A., Andrews, J.T., Ó Cofaigh, C., Hogan, K., Dowdeswell, J.A., 778 Seidenkrantz, M.-S., 2016. Ice stream retreat following the LGM and onset of the west 779 Greenland current in Uummannaq Trough, west Greenland. Quaternary Science Reviews, $780 \quad$ in press. http://dx.doi.org/10.1016/j.quascirev.2016.01.019.

781 Simpson, M.J.R., Milne, G.A., Huybrechts, P., Long, A.J., 2009. Calibrating a glaciological 782 model of the Greenland ice sheet from the Last Glacial Maximum to present-day using 783 field observations of relative sea level and ice extent. Quaternary Science Reviews 29, $784 \quad 1631-1657$.

785 Solignac, S., de Vernal, A., Hillaire-Marcel, C., 2004. Holocene sea-surface conditions in the 786 North Atlantic - contrasting trends and regimes in the western and eastern sectors 787 (Labrador Sea vs. Iceland Basin). Quaternary Science Reviews 23, 319-334.

788 Sparrenbom, C.J., Bennike, O., Björck, Lambeck, K., 2006a. Holocene relative sea-level changes 789 in the Qaqortoq area, southern Greenland. Boreas 35, 171-187

790 Sparrenbom, C.J., Bennike, O., Björck, Lambeck, K., 2006b. Relative sea-level changes since 79115000 cal. Yr BP in the Nanortalik area, southern Greenland. Journal of Quaternary $792 \quad$ Science 21, 29-48. 
793 Sparrenbom, C.J., Bennike, O., Fredh, D., Randsalu-Wendrup, L., Zwartz, D., Ljung, K., Björck,

794 S., Lambeck, K., 2013. Holocene relative sea-level changes in the inner Bredefjord area, 795 southern Greenland, Quaternary Science Reviews, 69, 107-124.

796 Storms, J.E.A., de Winter, I.L., Overeem, I., Drijkoningen, G.G., Lykke-Andersen, H., 2012. The $797 \quad$ Holocene sedimentary history of the Kangerlussuaq Fjord-valley fill, West Greenland. $798 \quad$ Quaternary Science Reviews 35, 29-50

799 Stroeven, A.P., Fabel, D., Hättestrand, C., Harbor, J., 2002. A relict landscape in the centre of 800 Fennoscandian glaciation: cosmogenic radionuclide evidence of tors preserved through 801 multiple glacial cycles. Geomorphology 44, 145-154.

802 Tarasov, L., Dyke, A.S., Neal, R.M., Peltier, W.R., 2012. A data-calibrated distribution of 803 deglacial chronologies for the North American ice complex from glaciological modeling. $804 \quad$ Earth and Planetary Science Letters 315-316, 30-40.

805 Tarasov, L., Peltier, W.R., 2002. Greenland glacial history and local geodynamic consequences. 806 Geophysics Journal International 150, 198-229.

807 Van der Veen, C.J., 2002. Calving glaciers. Progress in Physical Geography 26, 96-122.

808 Weidick, A., 1975. Holocene shorelines and glacial stages in Greenland —an attempt at 809 correlation. Rapport Grønlands Geologiske Undersøgelse 41, 39 pp.

810 Williams, K.M., 1993. Ice sheet and ocean interactions, margin of the East Greenland Ice Sheet 811 (14 ka to present): diatom evidence. Paleoceanography 8, 69-83.

812 Winsor, K., Carlson, A.E., Klinkhammer, G.P., Stoner, J.S., Hatfield, R.G., 2012. Evolution of 813 the northeast Labrador Sea during the last interglaciation. Geochemistry, Geophysics, $814 \quad$ Geosystems 13, http://dx.doi.org/10.1029/2012GC004263. 
815 Winsor, K., Carlson, A.E., Rood, D.H., 2014. ${ }^{10}$ Be dating of the Narsarsuaq moraine in 816 southernmost Greenland: evidence for a late-Holocene ice advance exceeding the Little 817 Ice Age maximum. Quaternary Science Reviews 98, 135-143.

818 Winsor, K., Carlson, A.E., Caffee, M., Rood, D.H., 2015a. Rapid last-deglacial thinning and 819 retreat of the marine-terminating southwestern Greenland ice sheet. Earth and Planetary $820 \quad$ Science Letters 426, 1-12.

821 Winsor, K., Carlson, A.E., Welke, B., Reilly, B., 2015b. Early deglacial onset of southwestern 822 Greenland ice-sheet retreat on the continental shelf. Quaternary Science Reviews 128, $823 \quad 117-126$.

824 Young, N.E., Briner, J.P., 2015. Holocene evolution of the western Greenland Ice Sheet: 825 assessing geophysical ice-sheet models with geological reconstructions of ice-margin 826 change. Quaternary Science Reviews 114, 1-17.

827 Young, N.E., Briner, J.P., Stewart, H.A.M., Axford, Y., Csatho, B., Rood, D.H., Finkel, R.C., 828 2011a. Response of Jakobshavn Isbrae, Greenland, to Holocene climate change. Geology $829 \quad 39,131-134$.

830 Young, N.E., Briner, J.P., Axford, Y., Csatho, B., Babonis, G.S., Rood, D.H., Finkel, R.C., 8312011 b. Response of a marine-terminating Greenland outlet glacier to abrupt cooling 8200 832 and 9300 years ago. Geophysical Research Letters 38, 833 http://dx.doi.org/10.1029/2011GL049639.

834 Young, N.E., Schaefer, J.M., Briner, J.P., Goehring, B.M., 2013a. A Be-10 production rate 835 calibration for the Arctic. Journal of Quaternary Science 28, 515-526. 
836 Young, N.E., Briner, J.P., Rood, D.H., Finkel, R.C., Corbett, L.B., Bierman, P.R., 2013b. Age of 837 the Fjord Stade moraines in the Disko Bugt region, western Greenland, and the 9.3 and $838 \quad 8.2$ ka cooling events. Quaternary Science Reviews 60, 76-90.

839 Young, N.E., Schweinsberg, A.D., Briner, J.P., Schaefer, J.M., 2015. Glacier maxima in Baffin 840 Bay during the Medieval Warm Period coeval with Norse settlement. Sci. Adv., $841 \quad$ e1500806.

842 Zweck, C., Huybrechts, P., 2005. Modeling of the northern hemisphere ice sheets during the last 843 glacial cycle and glaciological sensitivity. Journal of Geophysical Research: $844 \quad$ Atmospheres 110. http://dx.doi.org/10.1029/2004JD005489. 


\begin{tabular}{|c|c|c|}
\hline Study Title & Region & $\begin{array}{l}\text { Number of } \\
\text { Samples }\end{array}$ \\
\hline Håkanson et al. 2007a & Scoresby Sund & 4 \\
\hline Håkanson et al. 2007b & Store Koldewey & 7 \\
\hline Kelly et al. 2008 & Scoresby Sund & 38 \\
\hline Roberts et al. 2008 & Sermilik & 12 \\
\hline Håkanson et al. 2009 & Scoresby Sund & 43 \\
\hline Rinterknecht et al. 2009 & Sissimiut-Kangerlussuaq & 12 \\
\hline Roberts et al. 2009 & Sissimiut-Kangerlussuaq & 16 \\
\hline Moller et al. 2010 & Johannes V. Jensen Land & 16 \\
\hline Corbett et al. 2011 & Disko Bugt & 30 \\
\hline Håkanson et al. 2011 & Scoresby Sund & 14 \\
\hline Young et al. 2011a & Disko Bugt & 18 \\
\hline Young et al. 2011b & Disko Bugt & 8 \\
\hline Hughes et al. 2012 & Sermilik & 12 \\
\hline Levy et al. 2012 & Sissimiut-Kangerlussuaq & 9 \\
\hline Briner et al. 2013 & Disko Bugt & 2 \\
\hline Corbett et al. 2013 & Upernavik & 33 \\
\hline Kelley et al. 2013 & Disko Bugt & 12 \\
\hline Lane et al. 2013 & Uummannaq & 15 \\
\hline Larsen et al. 2013 & Nuuk & 47 \\
\hline Levy et al. 2014 & Scoresby Sund & 12 \\
\hline Lowell et al. 2013 & Scoresby Sund & 6 \\
\hline Roberts et al. 2013 & Uummannaq & 17 \\
\hline Young et al. 2013 & Disko Bugt & 21 \\
\hline Alexanderson and Håkansson 2014 & Scoresby Sund & 8 \\
\hline Carlson et al. 2014 & $\begin{array}{l}\text { Disko Bugt, Paamiut, Sissimiut- } \\
\text { Kangerlussuaq, Narsarsuaq }\end{array}$ & 29 \\
\hline Dyke et al. 2014 & Sermilik & 23 \\
\hline Nelson et al. 2014 & Narsarsuaq & 11 \\
\hline Rinterknecht et al. 2014 & Disko Bugt & 7 \\
\hline Winsor et al. 2014 & Narsarsuaq & 17 \\
\hline Corbett et al. 2015 & Thule & 28 \\
\hline Winsor et al. 2015 & $\begin{array}{l}\text { Narsarsuaq, Paamiut, Sissimiut- } \\
\text { Kangerlussuaq, Nuuk }\end{array}$ & 47 \\
\hline Kelley et al. 2015 & Disko Bugt & 18 \\
\hline Cronauer et al. 2015 & Disko Bugt & 11 \\
\hline Young et al. 2015 & Disko Bugt & 9 \\
\hline Larsen et al. 2016 & Johannes V. Jensen & 6 \\
\hline Corbett et al. 2016 & Thule & 28 \\
\hline Levy et al. 2016 & Scoresby Sund & 27 \\
\hline
\end{tabular}




\begin{tabular}{|c|c|}
\hline Study & Number of Samples \\
\hline Fredskild 1973 & 2 \\
\hline Kelly 1974 & 1 \\
\hline Kelly 1975 & 1 \\
\hline Weidick 1975 & 2 \\
\hline Funder 1979 & 1 \\
\hline Bennike et al. 2002 & 6 \\
\hline Kuijpers et al. 2003 & 16 \\
\hline Weidick et al. 2004 & 12 \\
\hline $\begin{array}{l}\text { Dyke } 2004 \text { (and references } \\
\text { therein) }\end{array}$ & 235 \\
\hline Lloyd et al. 2005 & 7 \\
\hline Jennings et al. 2006 & 41 \\
\hline Sparrenbom et al. 2006a & 30 \\
\hline Sparrenbom et al. 2006b & 38 \\
\hline Bennike 2007 & 1 \\
\hline Bennike and Sparrenbom 2007 & 3 \\
\hline Long et al. 2008 & 6 \\
\hline Long et al. 2009 & 9 \\
\hline $\begin{array}{l}\text { Nørgaard-Pedersen and } \\
\text { Mikkelsen } 2009\end{array}$ & 8 \\
\hline Briner et al. 2010 & 18 \\
\hline Bennike et al. 2011 & 9 \\
\hline Jennings et al. 2011 & 9 \\
\hline Larsen et al. 2011 & 10 \\
\hline Lloyd et al. 2011 & 1 \\
\hline Olsen et al. 2011 & 24 \\
\hline Young et al. 2011a & 3 \\
\hline Young et al. 2011b & 7 \\
\hline Bennike and Wagner 2012 & 5 \\
\hline Kelley et al. 2012 & 6 \\
\hline Massa et al. 2012 & 28 \\
\hline Storms et al. 2012 & 17 \\
\hline Briner et al. 2013 & 15 \\
\hline Lane et al. 2013 & 2 \\
\hline Levy et al. 2013 & 20 \\
\hline Lowell et al. 2013 & 55 \\
\hline Ó Cofaigh et al. 2013 & 19 \\
\hline Perner et al. 2013 & 16 \\
\hline Sparrenbom et al. 2013 & 15 \\
\hline Young et al. 2013 & 3 \\
\hline Briner et al. 2014 & 22 \\
\hline Håkansson et al. 2014 & 11 \\
\hline
\end{tabular}




\begin{tabular}{|lr|} 
Larsen et al. 2014 & 15 \\
Corbett et al. 2015 & 4 \\
Cronauer et al. 2015 & 6 \\
Sheldon et al. 2016 & 2 \\
Hogan et al. 2016 & 6 \\
\hline
\end{tabular}




\begin{tabular}{|cccc|}
\hline Factor number & Eigenvalues & $\begin{array}{c}\text { Percent variance } \\
\text { explained }\end{array}$ & $\begin{array}{c}\text { Cumulative percent } \\
\text { varience explained }\end{array}$ \\
\hline 1 & 33.8 & 39.3 & 39.3 \\
2 & 11.9 & 13.8 & 53.1 \\
3 & 9.5 & 11.0 & 64.1 \\
4 & 7.0 & 8.1 & 72.3 \\
5 & 4.6 & 5.4 & 77.6 \\
6 & 4.3 & 5.0 & 82.7 \\
\hline
\end{tabular}




\begin{tabular}{|rrrr|}
\hline Factor number & Eigenvalues & $\begin{array}{c}\text { Percent variance } \\
\text { explained }\end{array}$ & $\begin{array}{c}\text { Cumulative percent } \\
\text { varience explained }\end{array}$ \\
\hline 1 & 60.6801 & 28.6227 & 28.6227 \\
2 & 33.562 & 15.8311 & 44.4538 \\
3 & 20.9421 & 9.8783 & 54.3322 \\
4 & 14.6875 & 6.9281 & 61.2602 \\
5 & 12.1803 & 5.7454 & 67.0057 \\
6 & 8.7107 & 4.1088 & 71.1145 \\
7 & 6.6403 & 3.1322 & 74.2467 \\
8 & 5.3779 & 2.5367 & 76.7834 \\
9 & 4.4372 & 2.093 & 78.8764 \\
10 & 3.9669 & 1.8712 & 80.7476 \\
\hline
\end{tabular}




\begin{tabular}{|lrr|}
\hline \multicolumn{1}{|c}{ Region } & $\begin{array}{c}\text { Pearson's Correlation } \\
\text { Coefficient }\end{array}$ & P-value \\
\hline Thule & -0.323 & 0.177 \\
Upernavik & 0.108 & 0.643 \\
Uummannaq & -0.323 & 0.177 \\
Disko Bugt & -0.202 & 0.022 \\
Sissimiut-Kangerlussuaq & 0.103 & 0.529 \\
Nuuk & 0.160 & 0.310 \\
Paamiut & 0.057 & 0.806 \\
Narsarsuaq & 0.155 & 0.441 \\
Bernstorffs & -0.105 & 0.720 \\
Sermilik & 0.095 & 0.660 \\
Kangerdlussuaq & -0.596 & 0.158 \\
Scoresby Sund & -0.014 & 0.912 \\
Store Koldewey & 0.224 & 0.857 \\
Johannes V. Jensen Land & 0.576 & 0.008 \\
\hline
\end{tabular}




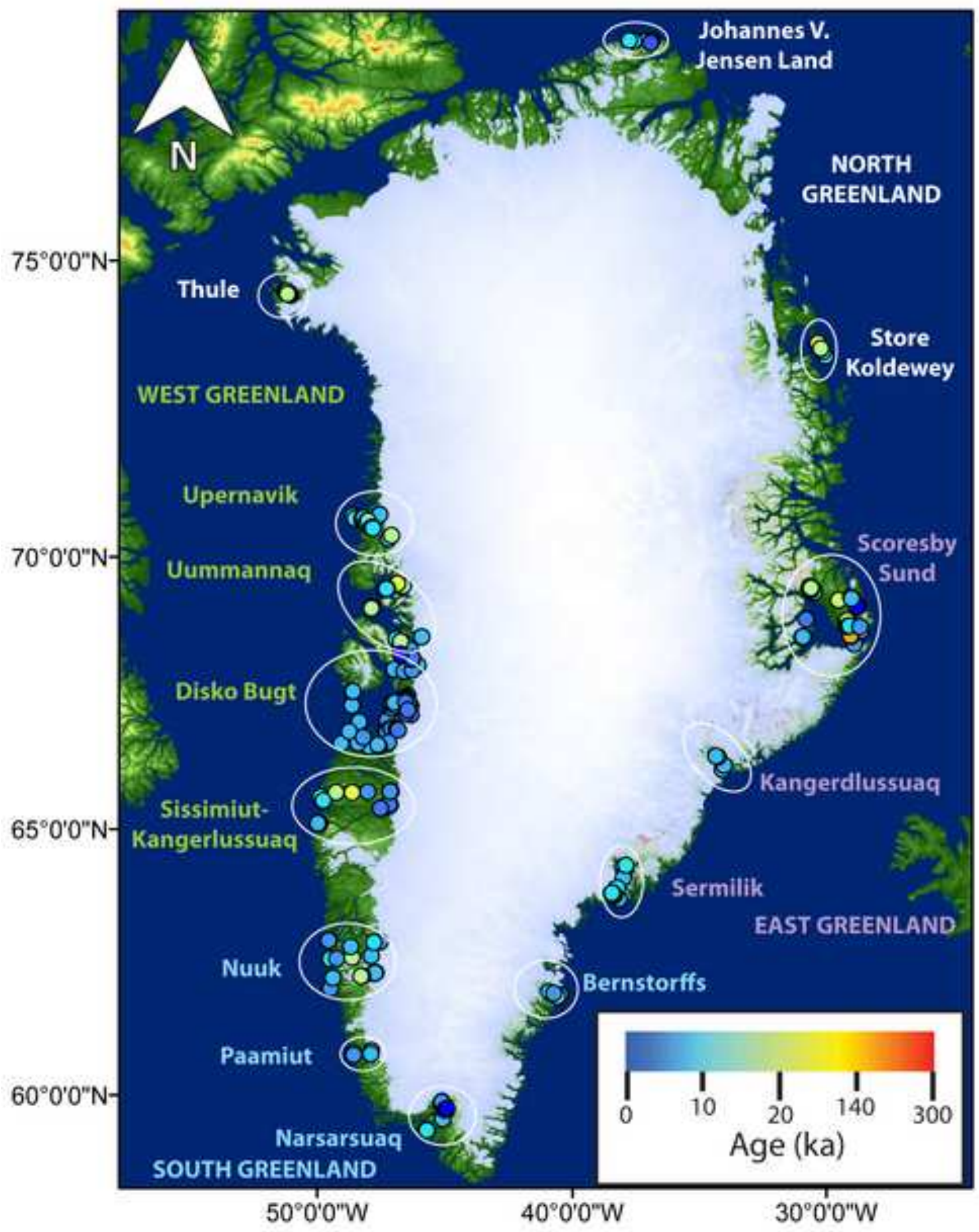


Figure 2

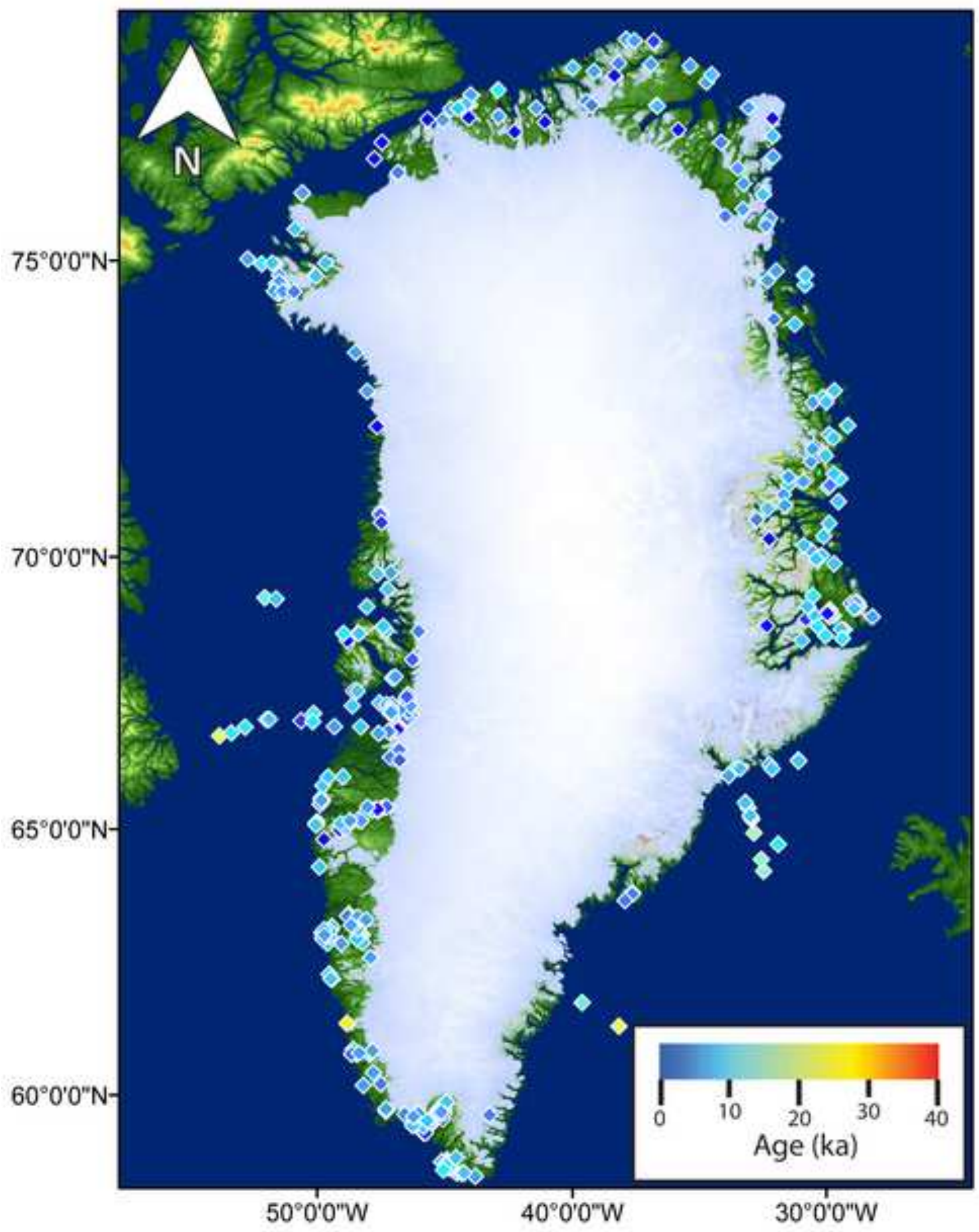


(1)

\section{Gridcell 1}

Gridcell 2

$\bullet$

-
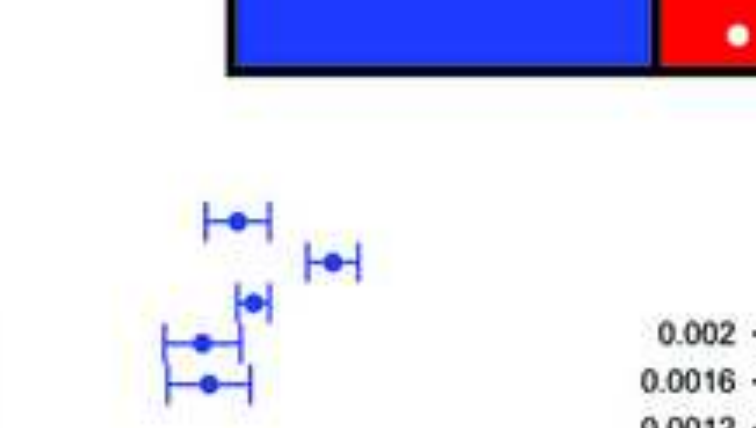

1.-

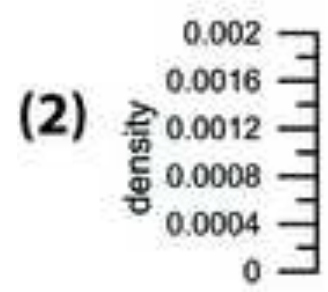

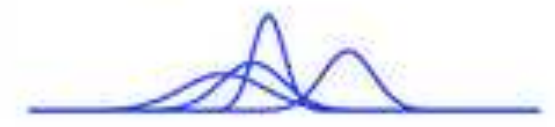

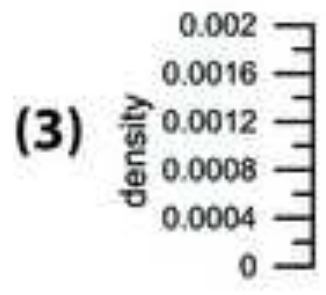
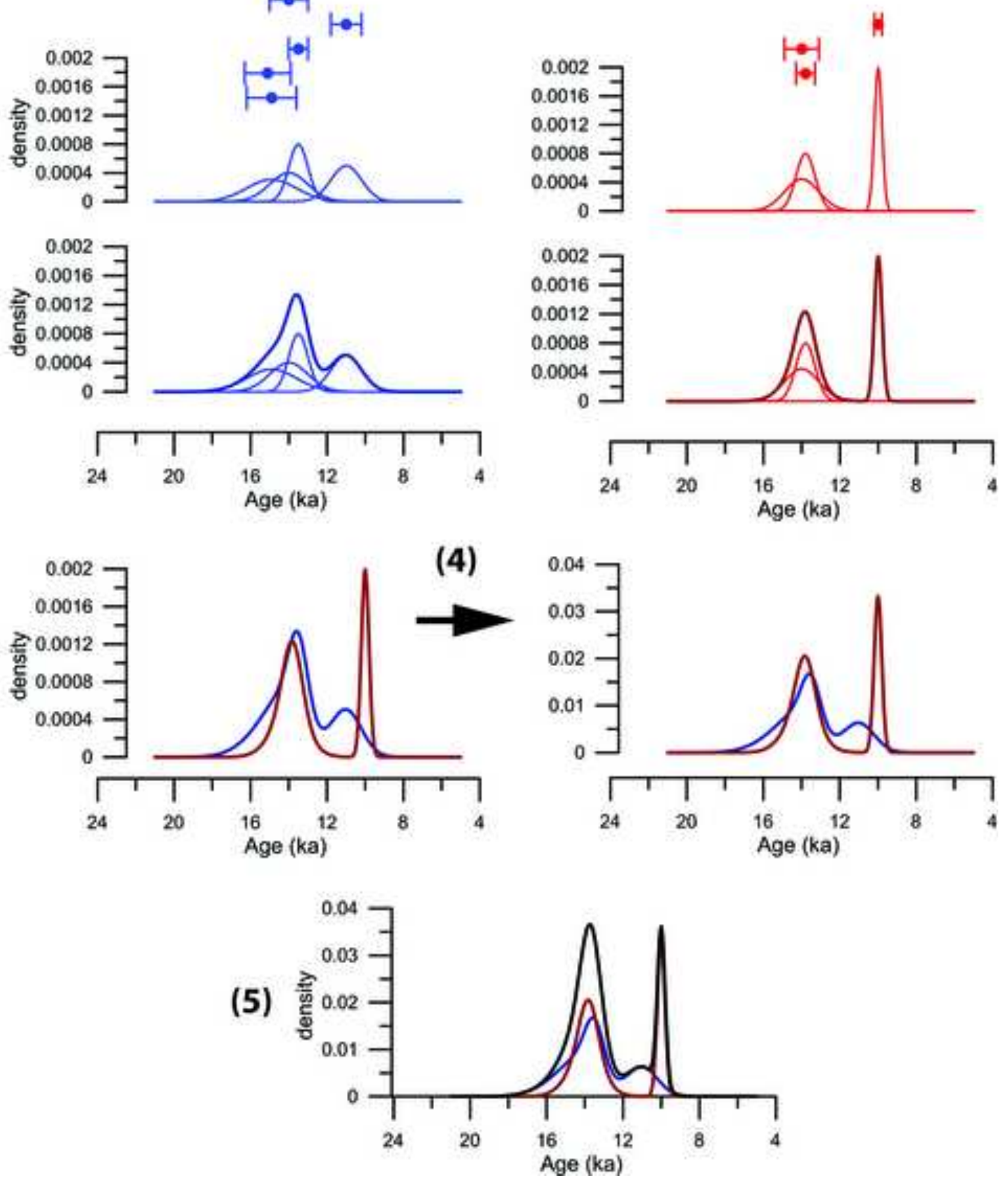


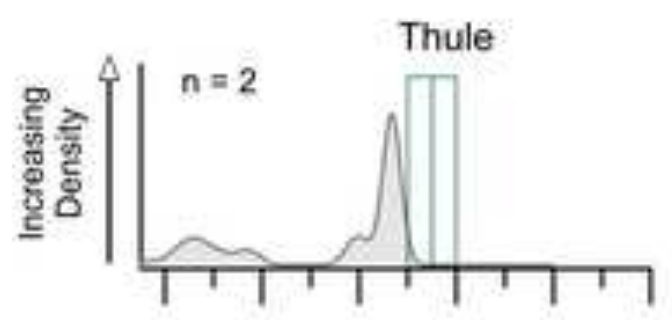

Upernavik

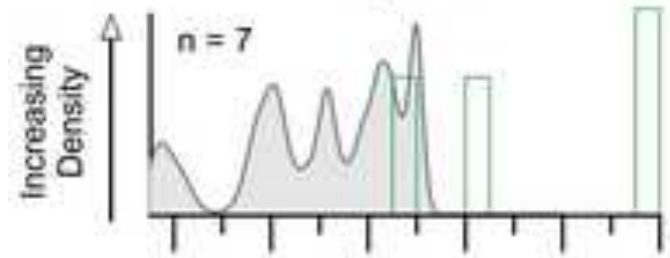

Uummannaq

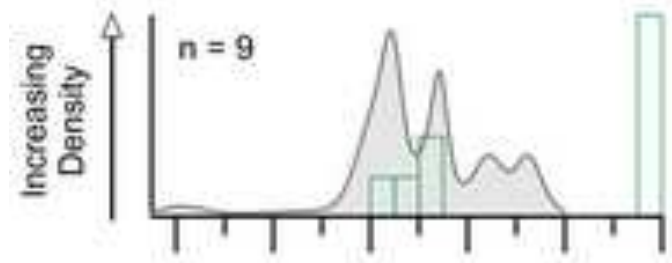

\section{Disko Bugt}

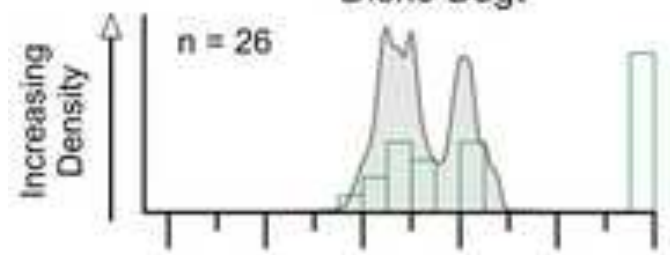

Sisimiut-Kangerlussuaq
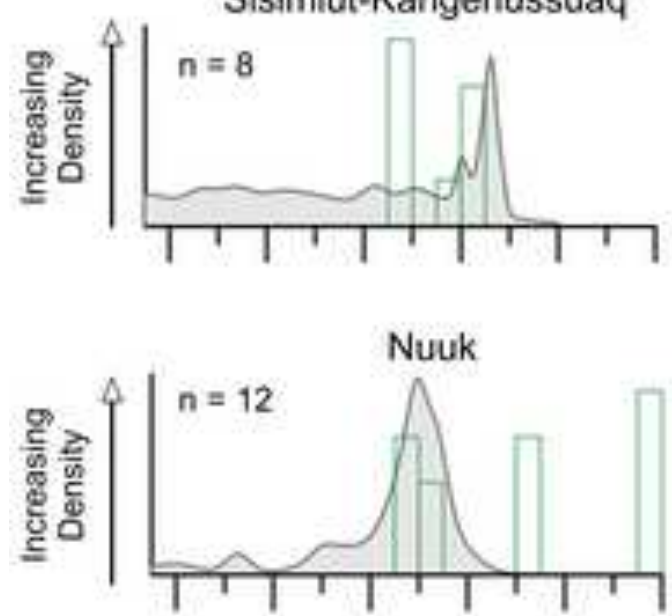

Paamiut

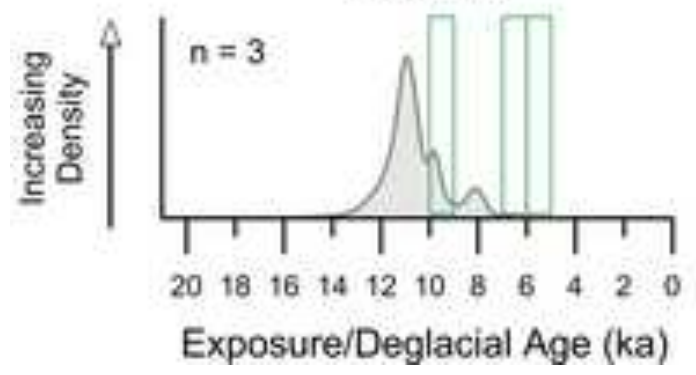

Johannes V. Jensen Land

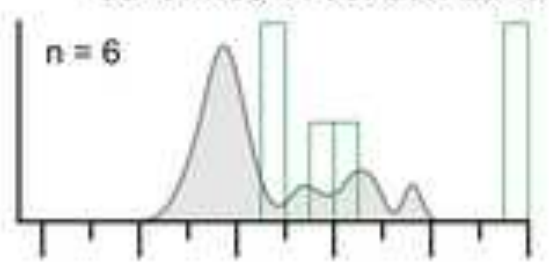

Store Koldewey

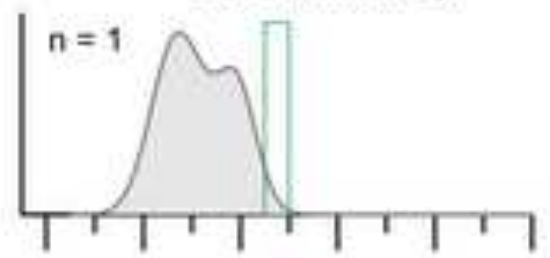

Scoresby Sund

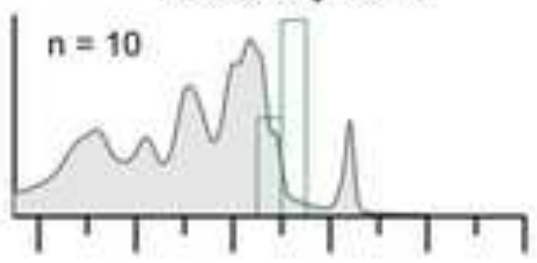

Kangerdlussuaq

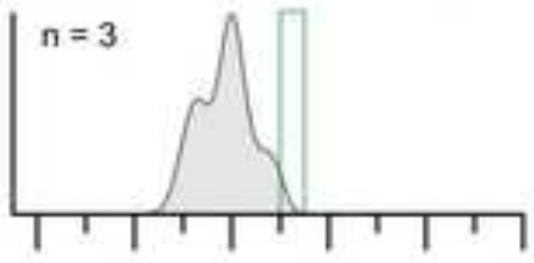

Sermilik
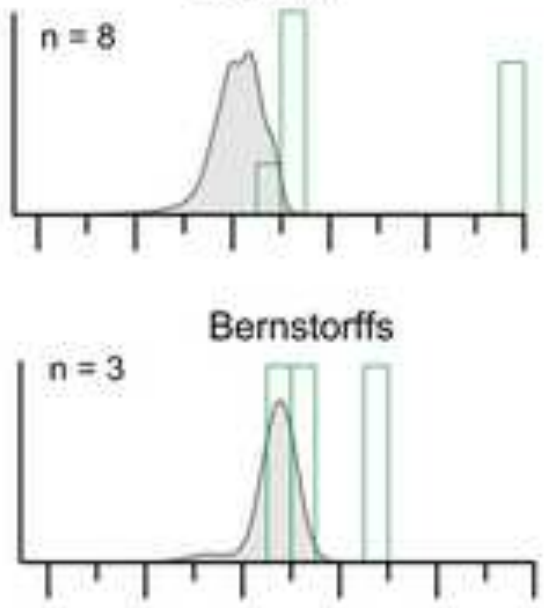

Narsarsuaq

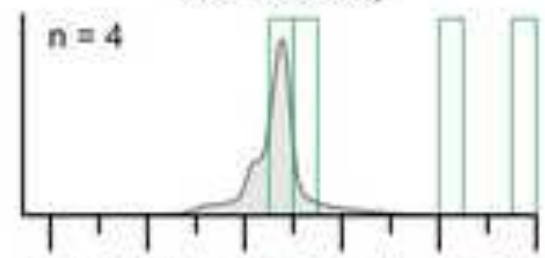

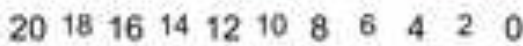

Exposure/Deglacial Age (ka) 

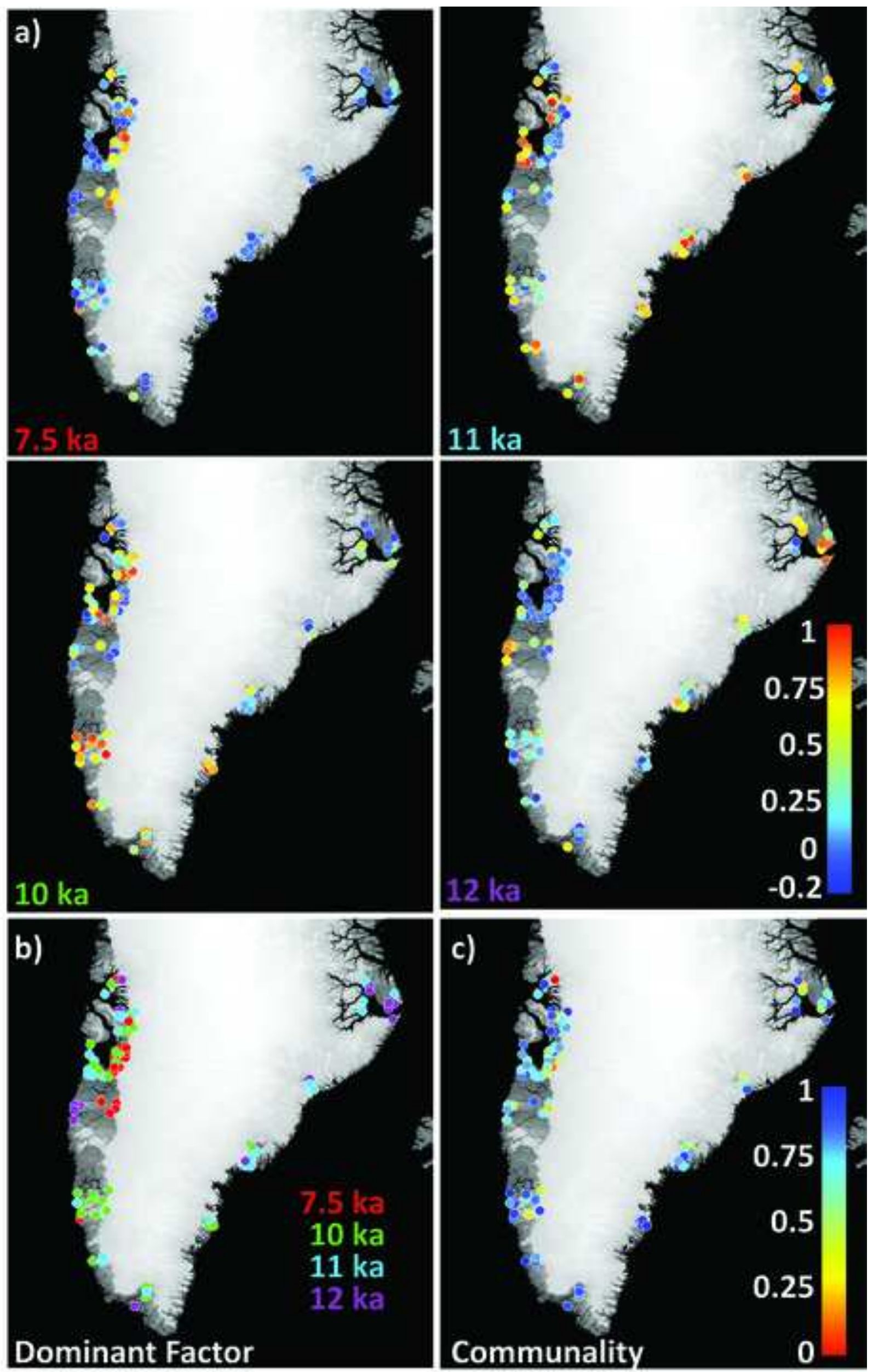


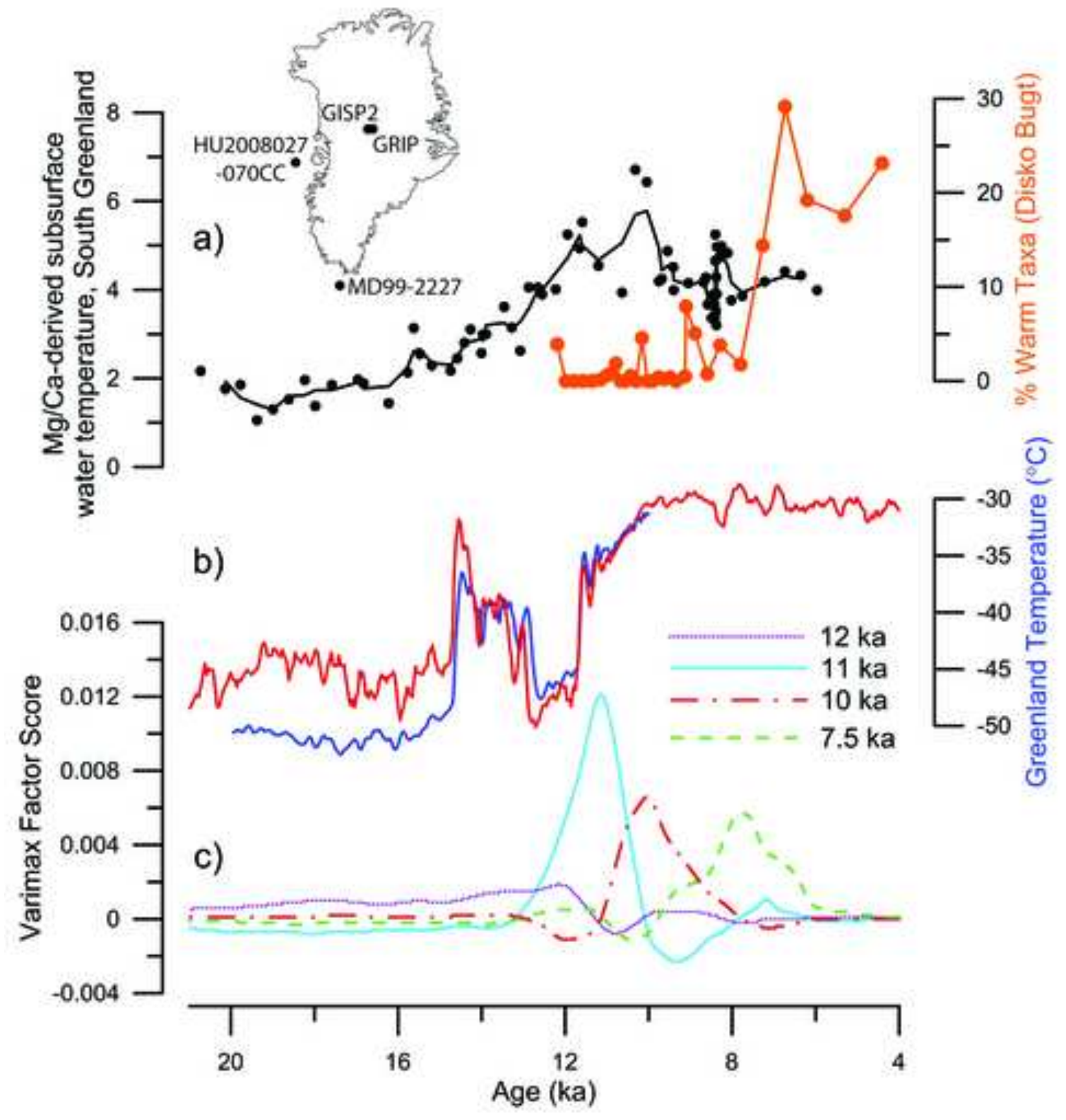




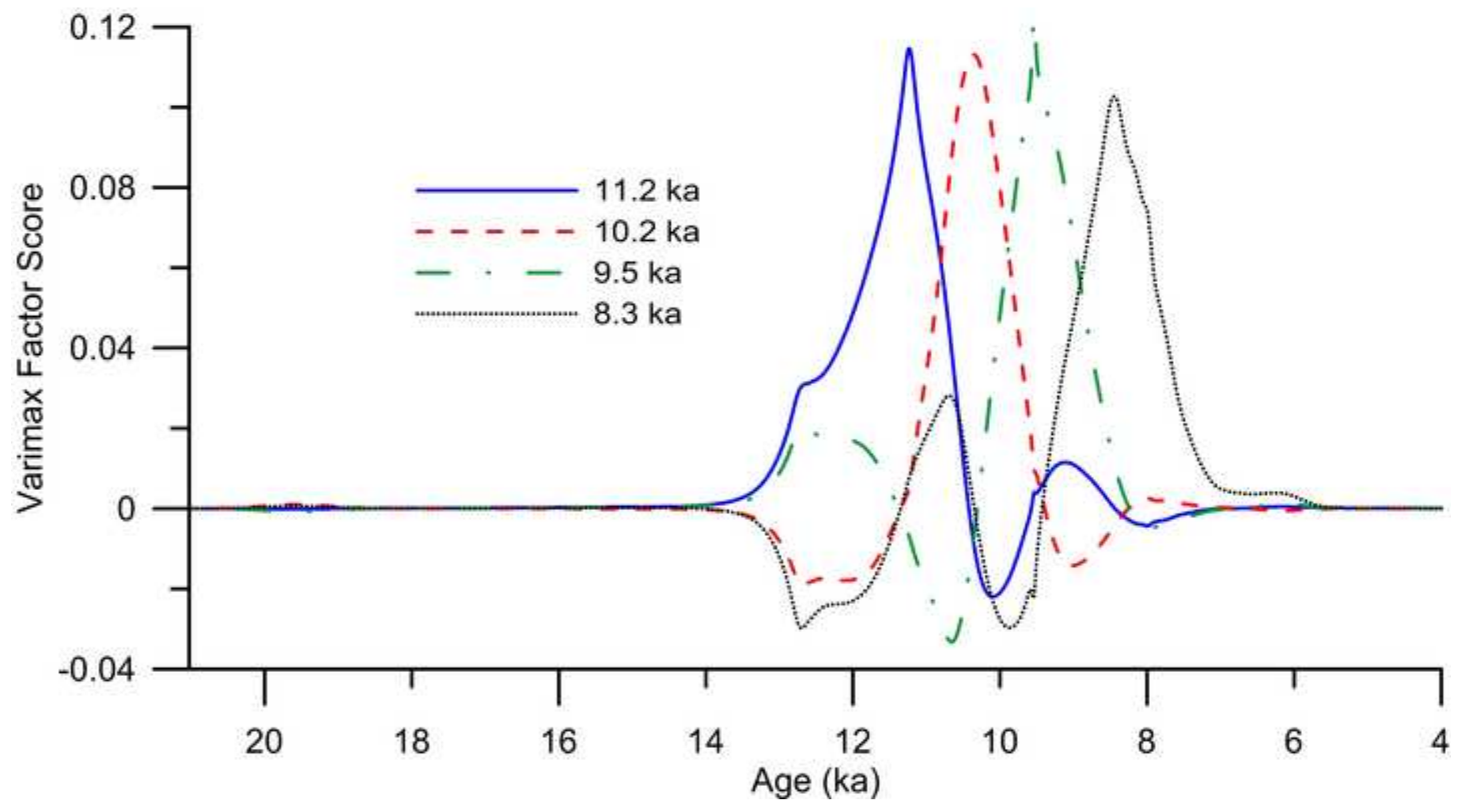



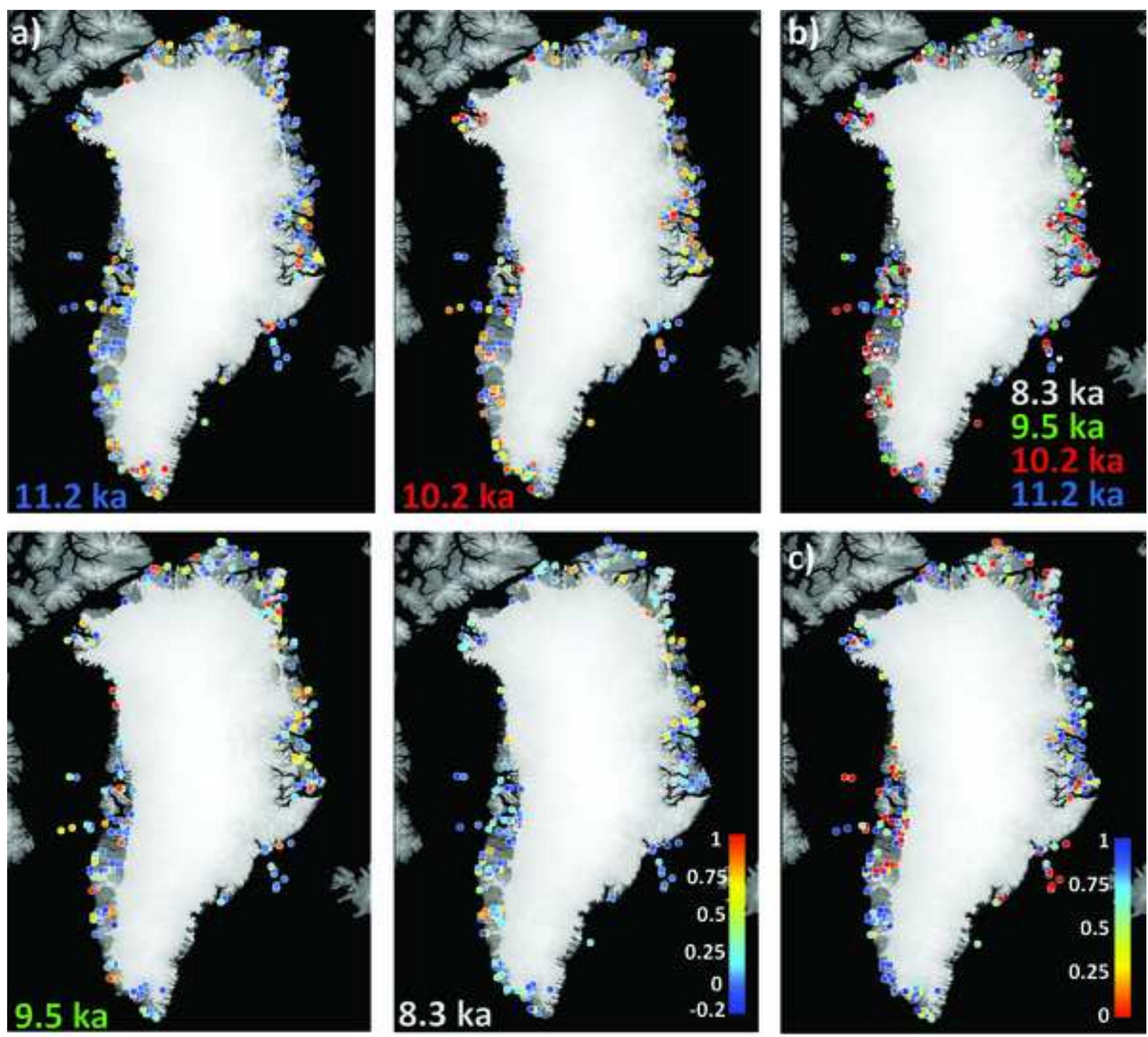


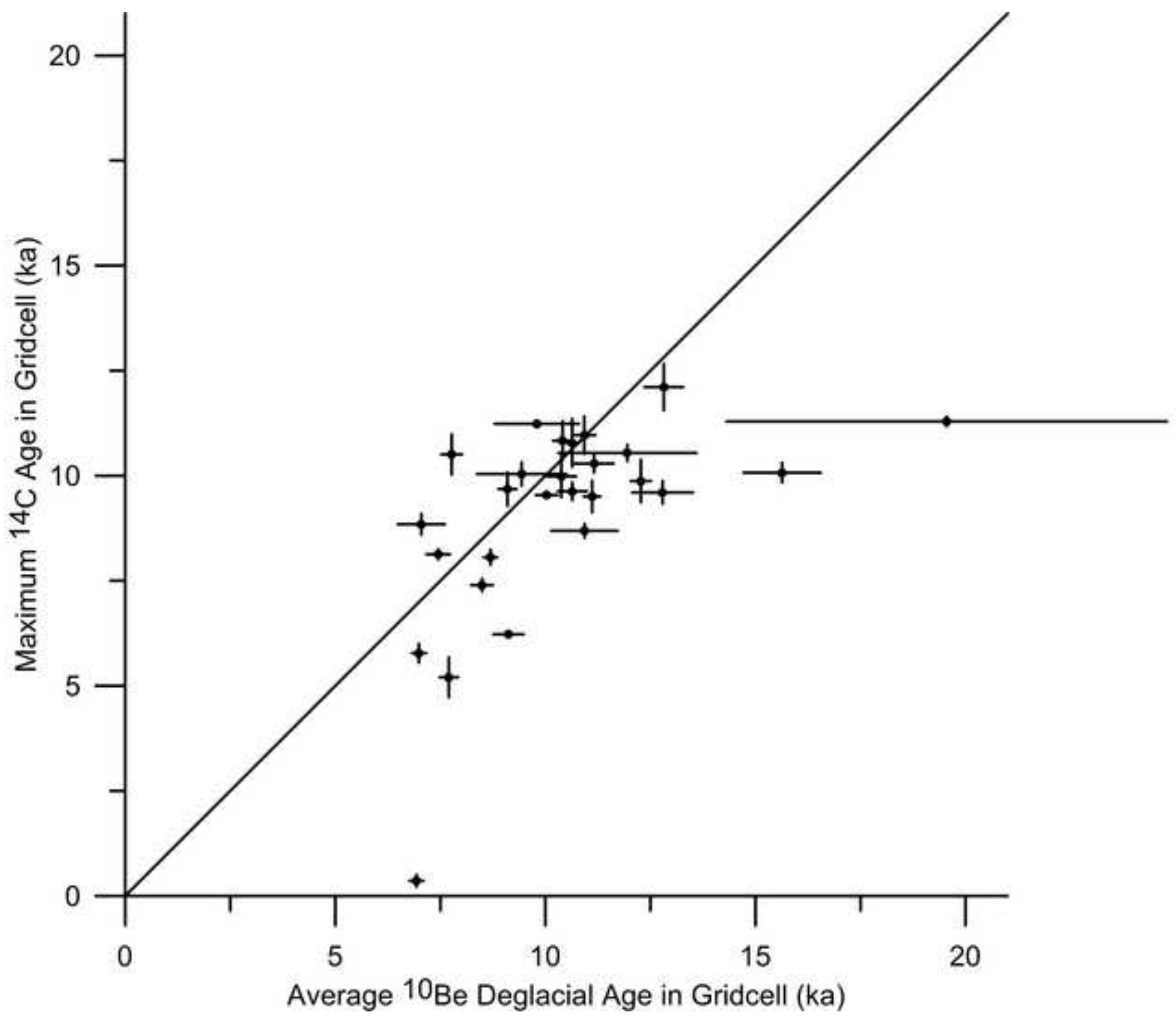




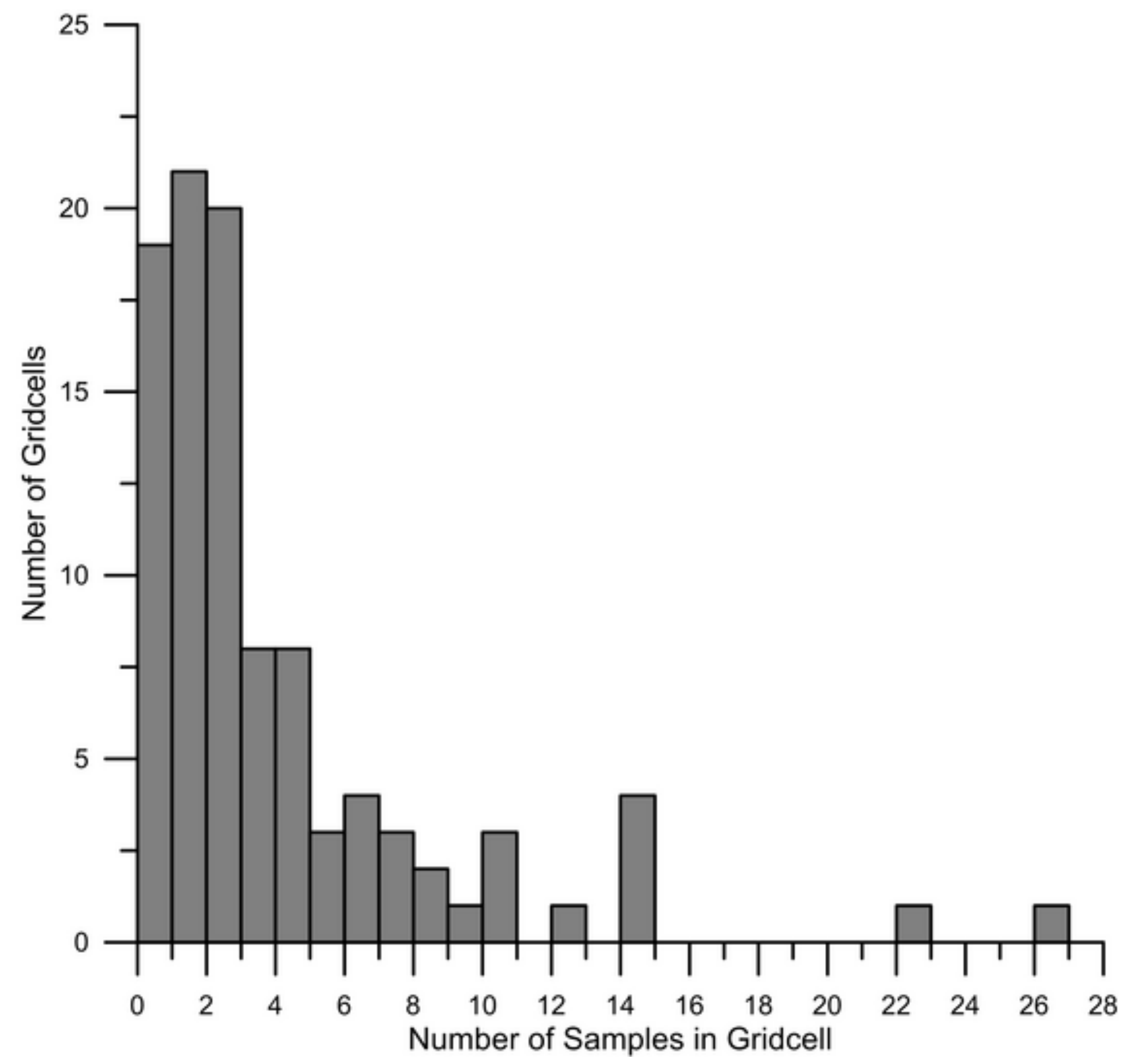




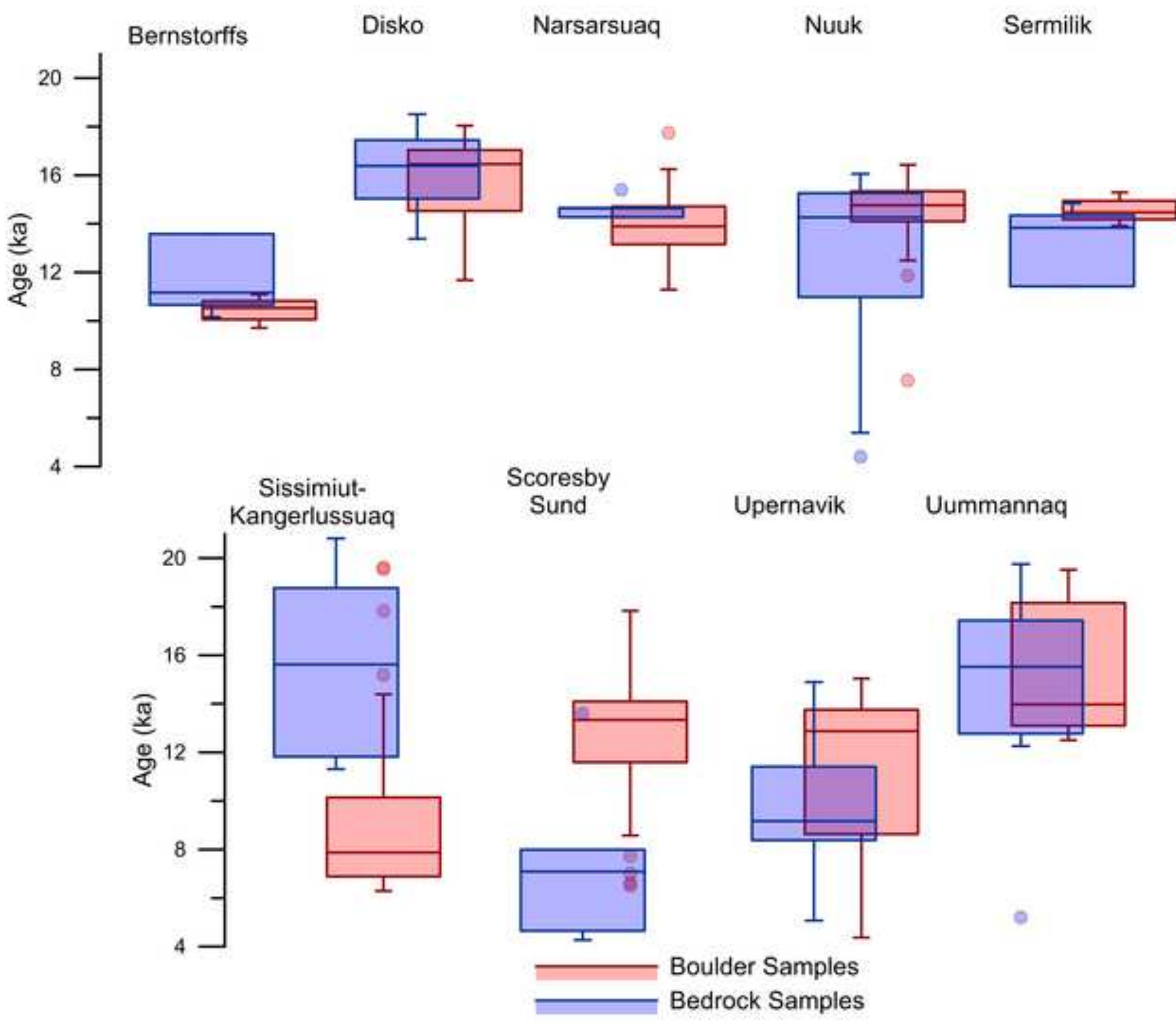

